\title{
Article
}

\section{The Required Amount of Ventilation Air for the Classroom and the Possibility of Air Infiltration through the Windows}

\author{
Piotr Lis ${ }^{1, *}$ and Anna Lis ${ }^{2}$ iD \\ 1 Faculty of Infrastructure and Environment, Czestochowa University of Technology, J.H. Dabrowskiego 73, \\ 42-201 Czestochowa, Poland \\ 2 Faculty of Civil Engineering, Czestochowa University of Technology, Akademicka 3, \\ 42-200 Czestochowa, Poland; anna.lis@pcz.pl \\ * Correspondence: piotr.lis@pcz.pl
}

Citation: Lis, P.; Lis, A. The Required Amount of Ventilation Air for the Classroom and the Possibility of Air Infiltration through the Windows. Energies 2021, 14, 7537. https:// doi.org/10.3390/en14227537

Academic Editor: Francesco Nocera

Received: 22 September 2021

Accepted: 9 November 2021

Published: 11 November 2021

Publisher's Note: MDPI stays neutral with regard to jurisdictional claims in published maps and institutional affiliations.

Copyright: (c) 2021 by the authors. Licensee MDPI, Basel, Switzerland. This article is an open access article distributed under the terms and conditions of the Creative Commons Attribution (CC BY) license (https:// creativecommons.org/licenses/by/ $4.0 /)$.

\begin{abstract}
The majority of education buildings in Poland are equipped with natural (gravity) ventilation, where the air inflow depends on the level of window airtightness. A complete statistical urban population of 50 school buildings in Czestochowa have been examined. The main issue to be clarified is the answer to the following questions: Is it theoretically possible to supply enough air to meet the ventilation requirements with gravity ventilation? What is the airtightness of the windows at which it will be possible? The average technical conditions of windows in the analysed buildings were bad. However, only in the case in which high external air leakage coefficient a $=7.0 \mathrm{~m}^{3} /\left(\mathrm{h} \mathrm{m} \mathrm{daPa}{ }^{2 / 3}\right)$ $\left(q_{100 \mathrm{KL}}=32.4912 \mathrm{~m}^{3} /(\mathrm{h} \mathrm{m})\right.$ is the amount of air passing through the leaks similar to the quantitative ventilation requirements for classrooms. The quantity of air flowing from the outside through modernized windows that meet the technical requirements $\left(a=0.6\right.$ to $\left.1.0 \mathrm{~m}^{3} /\left(\mathrm{m} \mathrm{h} \mathrm{daPa}^{2 / 3}\right)\right)$ covers on average only about $12 \%$ and about $21 \%$ of the ventilation needs. Without installing additional vents in the rooms, or better yet, installing mechanical ventilation with heat recovery, meeting the ventilation norm requirements will be impossible.
\end{abstract}

Keywords: educational building; classroom; window air-tightness; air infiltration; natural ventilation

\section{Introduction}

The issue of air quality, in rooms in which people spend a lot of time, has gained importance due to the relation between air quality and ventilation (and the restriction of ventilation), energy consumption of heating and comfort of the people using such spaces. The problem described is not neglected by regulations in the EU-e.g., European Standard EN 14351-1:2006+A2:2016 and EN 12207:2016. However, errors or abuses in this area are still prevalent [1,2]. Excessive and uncritical airtight sealing of buildings as well as attempts to drastically reduce the fresh air changes that result from implementation of a heating energy saving programme have a negative impact on the quality of air in rooms and thus on their microclimate. In the longer term, such a situation brings about the so-called sick-building syndrome, which causes many health problems [3-8]. The term sick-building syndrome refers to the situation where staying in a certain room or building can cause and intensify negative health conditions in the user, leading to weakness or even illness. This combination of ailments, called a syndrome, includes irritation of the eyes, respiratory tract or skin, nausea and headaches, discomfort, irritation, fatigue and concentration problems. These symptoms are closely related to improper microenvironment, especially poor air quality [9-13]. Studies have shown that excessive airtight sealing of a building, without ensuring a properly functioning ventilation system, may cause illnesses and ailments in up to $80 \%$ of the people staying in such a building [11].

The indicator most frequently used to represent air quality in rooms occupied by people is the concentration of $\mathrm{CO}_{2}$ e.g., [14-18]. Carbon dioxide is a major, but not the only type, of indoor air contamination. In the literature, we can find results of studies 
whose authors use indicators referring to other substances. These coefficients include concentrations of particulate matter (PM) of different sizes, concentrations of respirable suspended particulate matter (RSPM), concentrations of biological contaminants (bacteria concentration), unpleasant odours and other indices of contamination [19-24]. Reduction of ventilation also leads to the increase of relatively high air humidity, which is conducive to excessive development of various types of mould $[25,26]$.

Proper room ventilation is of particular importance for the comfort of work in education buildings. In this case, limiting ventilation for the sake of reducing heat loss from heated buildings usually has a negative impact on the quantity and quality of the fresh air and thus on the microclimate of classrooms and effectiveness of the teaching process [3,4,27-32]. Due to the increase in incidences of various types of allergies and asthma in students and teachers, the studies devoted to the quality of school environments have been intensified $[4,32-40]$. They have concentrated, among other things, on the direct impact of school environments on health deterioration, and have often indicated poor air quantity and quality as the primary cause of such problems.

The already-published works on education buildings confirm that concentration of $\mathrm{CO}_{2}$ generated mainly during metabolism is a very good and most frequently used measure of air quality in rooms [28,41-44]. As the analysis of $\mathrm{CO}_{2}$ concentration in classrooms shows, during classes the concentration of $\mathrm{CO}_{2}$ gradually increases [30,37,44-46]. Its gradual fall could be noticed only after all the classes end. This indicates, with high probability, that either regular and effective ventilation of the classroom during brakes was avoided, or performance of the ventilation system was insufficient, without taking into account for the time being, the issue of whether the maximum allowable concentrations of $\mathrm{CO}_{2}$ were exceeded or not. As determined by the European branch of the World Health Organization [35] and the American Society of Heating, Refrigeration and Air-conditioning Engineers [47], the permissible concentration of carbon dioxide in closed spaces is $1000 \mathrm{ppm}$ $(0.1 \%)$, which is a requirement of the so-called hygienic minimum. This acceptable limit is often exceeded, reaching (in the classrooms) such values as high as $4000 \mathrm{ppm}[28,36,48-51]$. The presented phenomena are very common in education buildings with natural (gravity) ventilation systems dominant in Poland, as well as in the countries with similar climate. These issues escalate during the heating season. Due to low outside air temperatures in the winter period people tend to avoid opening windows, which would create a more intensive ventilation. The situation is similar in education buildings that have been thermally upgraded, but where the existing natural ventilation system has not been changed into a more effective one [44,52-54].

In the operating system of natural (gravity) ventilation, fresh air flows into rooms mainly through leaks in windows and doors or through the air inlet vents installed in exterior walls, and the 'used air' is carried away in naturally through ventilation ducts. Such a ventilation system is sensitive for example to the changes of pressure, wind direction and speed, location of the building in the terrain and its position with respect to cardinal directions. This system practically makes satisfactory user control impossible and its relies mostly on facilitating the inflow of sufficient amounts of fresh air. The system, however, is used in a large number of education buildings. For this reason, this analysis will focus mainly on the particular importance of windows, which are critical in education buildings for at least three groups of inter-related issues connected with the use of rooms, which include:

- functional characteristics of buildings related to ensuring appropriate lighting conditions;

- seasonal heat consumption for the purpose of heating the classroom, due to the fact that the thermal insulation of windows is usually much worse than that of exterior walls;

- natural (gravity) ventilation of rooms where fresh air flows in through the windows with a specific air leakage coefficient $a$ (in Poland), expressed in $\mathrm{m}^{3} /\left(\mathrm{h} \mathrm{m} \mathrm{daPa}{ }^{2 / 3}\right)$ or $q_{100 K L}$ expressed in $\mathrm{m}^{3} /(\mathrm{h} \mathrm{m})$ and which ensures or does not ensure inflow of the required amounts of fresh air into the room, even when the windows are closed. 
Bearing in mind the title of this paper and the considerations carried out in the introduction, the purpose, subject and scope of the research and analyses presented in the next part should be clearly explained. The main purpose was to calculate the theoretical amount of outside air that could be supplied to an average classroom through window leaks for ventilation of this room at the average wind speed for the analyzed area. The theoretical amount of air flowing into the classroom was calculated, depending on the technical condition of the windows and the related tightness of the windows. The calculated amount of air was compared with the requirements for the amount of air needed for proper ventilation of the classroom. The main issue to be clarified in the present paper is the answer to the following questions:

- Is it theoretically possible to supply enough air to satisfy the ventilation requirements? What is the tightness of the windows to make this possible?

- What are the consequences of the analysis results for the functioning of the gravity ventilation system?

- What are the consequences of the results of the conducted analysis for the modernization and thermo-modernization of school buildings?

Answers to the above questions will form the basis of the analysis referred to later in this paper as the theoretical analysis of functioning of natural (gravity) ventilation in class-rooms.

The issues essential for the subject of this paper were supplemented with statistical characteristics of the analyzed education buildings, classrooms and windows in these rooms. The above-mentioned elements are the subject of research and create an important environment for the conducted considerations. For this reason, they deserve a broader description based on our own research and statistical analysis.

The subject of research and analysis are all school buildings in Czestochowa. They form the complete urban statistical population of this type of education buildings. The scope of the paper presented is limited by the primary purpose of research and analysis.

The presented paper is the original material presenting the results of original research and analyses carried out by the authors.

\section{Research}

The presented analysis and its results are a small fragment of wider examinations of education buildings localized in the town of Czestochowa in southern Poland. All school buildings in the city where primary schools are located were examined and analyzed.

The overall logical structure of research and analysis to achieve a pre-defined purpose and answer the questions was the following:

- calculation of the cubature of an average classroom in a given object;

- establishment of the number of people staying in an average classroom in a given object;

- calculation of a normative quantity of fresh air with respect to the classroom cubature;

- calculation of a normative quantity of fresh air with respect to the number of students staying in the classroom;

- comparison of calculated values and establishment of which one of them is higher;

- establishment of the number and location of windows in the school, including the windows considered to be typical for a given object;

- establishment of the number of typical windows per average classroom;

- $\quad$ establishment of the perimeter of windows and opening sashes per classroom;

- establishment of the length and dimensions of leaks in typical windows, found in an average (for a given building) classroom;

- calculation of the probable quantity of outdoor air flowing into the classroom with respect to the local climate and technical conditions;

- refinement of the comparison of the requirements concerning ventilation of analysed rooms with the probable existing situation in this respect;

- drawing conclusions. 


\subsection{Methodology}

The full statistical examinations included all school buildings in the city where primary schools are located, and they were conducted by stages. A method of ad hoc statistical census was applied here, with the use of selected measures of descriptive statistics and correlation analysis. The statistical observation was carried out by correspondence and direct surveys, interviews, site inspections and personally conducted measurements. The research material obtained in this manner is primary material, collected especially for the purposes of conducting statistical examinations.

The meteorological conditions related to the wind, especially its speed and direction, are important for the conducted analyses. It should be remembered that wind with appropriate characteristics can support or impede proper functioning of the natural (gravity) ventilation system of the building where window leaks allow inflow of fresh air from the outside. Terrain relief and shading may reduce or intensify the said effects. Therefore, taking this into account when considering the location of the building, the wind rose for the town of Czestochowa should be considered. On the basis of the data gathered by the author, which include their own data and calculations based on meteorological data from the Institute of Meteorology and Water Management in Katowice, data concerning wind speed obtained from Polish meteorological stations and data presented in other sources, it has been established that the analysed terrain may be classified as a region with mild windiness $w_{a v}<5 \mathrm{~m} / \mathrm{s}$ (weak and moderate wind) [55,56]. During the heating season the wind here usually blows from the west, south-west and south.

Results of the conducted research and analyses will be presented later in the form of graphs showing changes in the values crucial for the discussed problems, and graphs of relationships which were the starting point for drawing the conclusions. In the graphs of value changes, trendlines were used, in the form of curves, and were described with a sixth-degree polynomial. In the case of the graphs of relations, the trendline in the form of curves described with a second-degree polynomial was used, and additionally, the value of the determination coefficient for these functions was provided, as $\mathrm{R}^{2}$. The paper does not present, however, the calculations on the basis of which said graphs were prepared, due to their secondary importance. Further steps of their implementation, as well as the basic assumptions which make their reconstruction possible, are presented below.

\subsection{Educational Buildings and Classrooms}

The presented analysis and its results are a fragment of wider examinations of education buildings, which were constructed between 1913 and 1992. They form a full municipal complex of 50 objects. These buildings make up a complete urban statistical population of objects of this type in which primary schools are operated. Complete statistical analysis included all members of this population and was conducted in stages in cooperation with the Municipal Office. The basic characteristics of this group of buildings, including the values essential for the deliberations presented in this paper, are shown in Table 1, with the use of selected measures of statistical description.

Classrooms of the analysed education buildings had an average usable area $\left(A_{c}\right)$ of approx. $50.44 \mathrm{~m}^{2}$ and an average ceiling height of approx. $4.15 \mathrm{~m}$ (classrooms had a height of $3.15 \mathrm{~m}$ to just over $5.0 \mathrm{~m}$ ). The average value of the coefficient indicating the area of the classroom per one student staying in it $\left(A_{\mathcal{S S}}\right)$ was approx. $1.58 \mathrm{~m}^{2}$, with typical values ranging from $1.28-2.11 \mathrm{~m}^{2}$. These values are not significantly different from classrooms in other countries with similar education system standards. On the basis of the data published in the works of other authors, it was established that the average usable area of a classroom was approximately $55 \mathrm{~m}^{2}$, whilst the area of classroom per one student was between 1.8-2.4 $\mathrm{m}^{2} /$ student $[3,4,34,37-40,57]$. According to the European standard EN 16798-1:2019 this value must be at least at the level of $2.0 \mathrm{~m}^{2} /$ student [58].

The basic characteristics of classrooms, including the values essential for the deliberations presented in this paper, are shown in Table 2 with the use of selected measures of statistical description. 
Table 1. Selected measures of statistical description for the values characterising 50 education buildings.

\begin{tabular}{|c|c|c|c|c|c|}
\hline \multirow{3}{*}{ Value $(x)$} & \multicolumn{5}{|c|}{ Selected Measures of Statistical Description } \\
\hline & Average Value & $\begin{array}{l}\text { Standard } \\
\text { Deviation }\end{array}$ & $\begin{array}{l}\text { Limits of } \\
\text { Typicality }\end{array}$ & $\begin{array}{l}\text { Coefficient of } \\
\text { Variation }\end{array}$ & Skewness \\
\hline & $x_{a v}$ & $s(x)$ & $x_{\text {typ }}$ & $V_{k}(x)[\%]$ & $S(x)$ \\
\hline Volume of the building, $V\left[\mathrm{~m}^{3}\right]$ & $14,682.37$ & 9674.55 & $5007.82-24,356.92$ & 65.89 & 1.53 \\
\hline Usable area of a building, $P_{u}\left[\mathrm{~m}^{2}\right]$ & 3194.09 & 2161.41 & $1032.67-5355.50$ & 67.67 & 1.54 \\
\hline Number of classrooms, $N_{\mathcal{c}}$ & 21 & 12 & $9-33$ & 58.48 & 1.68 \\
\hline $\begin{array}{l}\text { Ratio of the area of external envelope to } \\
\text { cubic capacity, } A_{e p} / V\left[\mathrm{~m}^{1}\right]\end{array}$ & 0.40 & 0.09 & $0.31-0.50$ & 23.43 & 1.13 \\
\hline Thermal power, $q[\mathrm{~kW}]$ & 323.38 & 235.15 & $88.23-558.54$ & 72.72 & 1.71 \\
\hline$q / V$ indicator, $\left[\mathrm{W} /\left(\mathrm{m}^{3} \mathrm{y}\right)\right]$ & 21.93 & 5.11 & $16.81-27.04$ & 23.32 & -0.11 \\
\hline $\begin{array}{l}\text { Heat consumption, } \\
\qquad[\mathrm{G} / \mathrm{y}]\end{array}$ & 1996.52 & 1266.14 & $730.38-3262.66$ & 63.42 & 1.07 \\
\hline$Q / V$ indicator, $\left[\mathrm{GJ} /\left(\mathrm{m}^{3} \mathrm{y}\right)\right]$ & 138.36 & 39.26 & $99.10-177.62$ & 28.37 & 1.34 \\
\hline
\end{tabular}

Table 2. Selected measures of statistical description for the values characterizing classrooms in 50 education buildings.

\begin{tabular}{|c|c|c|c|c|c|}
\hline \multirow{3}{*}{ Value $(x)$} & \multicolumn{5}{|c|}{ Selected Measures of Statistical Description } \\
\hline & Average Value & $\begin{array}{c}\text { Standard } \\
\text { Deviation }\end{array}$ & $\begin{array}{l}\text { Limits of } \\
\text { Typicality }\end{array}$ & $\begin{array}{l}\text { Coefficient of } \\
\text { Variation }\end{array}$ & Skewness \\
\hline & $x_{a v}$ & $s(x)$ & $x_{\text {typ }}$ & $V_{k}(x)[\%]$ & $S(x)$ \\
\hline Volume of the building, $V\left[\mathrm{~m}^{3}\right]$ & $14,682.37$ & 9674.55 & $5007.82-24,356.92$ & 65.89 & 1.53 \\
\hline Usable area of building, $P_{u}\left[\mathrm{~m}^{2}\right]$ & 3194.09 & 2161.41 & $1032.67-5355.50$ & 67.67 & 1.54 \\
\hline Number of classrooms, $N_{c}$ & 21 & 12 & $9-33$ & 58.48 & 1.68 \\
\hline Usable area of classroom, $A_{c}\left[\mathrm{~m}^{2}\right]$ & 50.44 & 8.12 & $42.32-58.56$ & 16.10 & 0.02 \\
\hline Number of students in classroom, $N_{s c}$ & 29 & 9 & $22-40$ & 29.62 & 2.02 \\
\hline $\begin{array}{l}\text { Usable area of classroom per student, } \\
\qquad A_{c s}=\left(A_{c} / N_{s c}\right)\left[\mathrm{m}^{2}\right]\end{array}$ & 1.58 & 0.41 & $1.28-2.11$ & 24.38 & 0.21 \\
\hline
\end{tabular}

\subsection{Windows in Classrooms}

The area and layout of windows on the individual façades of education buildings have an impact not only on energy consumption but also on the occupancy conditions. What follows from this, is that there are direct relations between solar heat losses and gains and daylight illumination of classrooms, and possible ways of getting an amount of fresh air into the rooms that is sufficient for proper functioning of the natural ventilation system. These relations follow from a certain kind of common denominator for the issues addressed here. This common denominator includes the windows of an educational building as well as the impact of certain values characteristic for such external barriers on the said issues. For this reason the following factors were analysed:

- $\quad$ simplified daylight illuminance indicator, defined as a ratio of windows area $A_{w}$ to the usable area $A_{u}$, and designated as $A_{w} / A_{u}$;

- $\quad$ façade glazing indicator, defined as a ratio of windows area $A_{w}$ to the area of exterior walls together with windows (the façades area) $A_{f}$, designated as $A_{w} / A_{f}$.

When discussing the issues of ventilation and air permeability of windows it should be kept in mind that the speed and direction of wind may be of high importance. Due to the said directions of the wind, the surfaces of educational building windows installed on the western and southern façades seem to be important. For this reason the analyses also 
covered the values of the glazing indicator for the façades facing the south $S A_{w}$ and all the way to the west $W A_{w}$.

Another point worth paying attention to, in the context of natural ventilation of rooms, is the division of the window area into opening sashes. The main value here is the perimeter of opening sashes $\left(P_{s t w}\right)$ in the windows typical for a given building. It seems that in this case, the form relatively often prevails over functional aspects of the window. Therefore, in the case of quite large areas of typical windows $\left(A_{t w}\right)$ that also have large areas of opening sashes, long-term use of windows and the accompanying technical wear, you can expect that many defects may occur and technical conditions of windows may deteriorate significantly.

These effects include, for example, excessive air permeability and excessive infiltration from the outside of cold air, which in the heating season must be heated. The permeability is excessive from the point of view of heating of rooms, however, not so much when it comes to the need for a sufficient fresh air inflow. A similar situation may occur in the case of windows the shape of which are characterised by high proportions of the perimeter of a typical window $\left(P_{t w}\right)$ to its area $\left(A_{t w}\right)$. In the case of typical windows used in the Polish house-building industry, approximate values of the quotient $\left(P_{s t w} / A_{t w}\right)$ are the following: (4.3-4.8) $\mathrm{m} / \mathrm{m}^{2}$ for single sash windows, $(4.0-4.8) \mathrm{m} / \mathrm{m}^{2}$ for double sash windows, (4.4-5.4) $\mathrm{m} / \mathrm{m}^{2}$ for triple sash windows and $3.4 \mathrm{~m} / \mathrm{m}^{2}$ for single sash balcony door [59].

In the case of windows in education buildings, which often have a larger area and non-standard division, different than that normally used in the house-building industry, the previously listed values $\left(P_{s t w} / A_{w}\right)$ may be different. As a result of local inspections, examinations and measurements, it was found that in the case of every building, the majority of windows have identical shapes and dimensions. The decision was made to treat such windows as typical for a given building. The analysed classroom windows are typical windows. For this reason, the following characteristics for typical windows in classrooms were analysed: area of typical window $A_{t w}$, perimeter of typical window $P_{t w}$, perimeter of opening sashes $\left(P_{s t w}\right)$ in the typical windows, $P_{s t w} / A_{t w}$.

The basic characteristics of windows in the analysed buildings, including the values essential for the deliberations presented in this paper, are shown in Table 3, with the use of selected measures of statistical description.

Table 3. Selected measures of statistical description for the values characterising windows in 50 education buildings.

\begin{tabular}{|c|c|c|c|c|c|}
\hline \multirow{3}{*}{ Value $(x)$} & \multicolumn{5}{|c|}{ Selected Measures of Statistical Description } \\
\hline & Average Value & $\begin{array}{l}\text { Standard } \\
\text { Deviation }\end{array}$ & $\begin{array}{l}\text { Limits of } \\
\text { Typicality }\end{array}$ & $\begin{array}{l}\text { Coefficient of } \\
\text { Variation }\end{array}$ & Skewness \\
\hline & $x_{a v}$ & $s(x)$ & $x_{t y p}$ & $V_{k}(x)[\%]$ & $S(x)$ \\
\hline $\begin{array}{l}\text { Ratio of the windows area to the } \\
\text { façades area, } A_{w} / A_{f}\end{array}$ & 0.24 & 0.05 & $0.19-0.30$ & 21.73 & -0.11 \\
\hline $\begin{array}{l}\text { Ratio of the windows area to usable } \\
\text { area, } A_{w} / A_{u}\end{array}$ & 0.20 & 0.06 & $0.15-0.26$ & 27.43 & 0.07 \\
\hline Area of a typical window, $A_{t w}\left[\mathrm{~m}^{2}\right]$ & 4.49 & 2.73 & $3.84-5.28$ & 68.88 & 4.12 \\
\hline Perimeter of a typical window, $P_{t w}[\mathrm{~m}]$ & 8.38 & 2.34 & $6.04-10.72$ & 27.98 & 3.16 \\
\hline $\begin{array}{l}\text { Perimeter of a opening sashes in a } \\
\text { typical window, } P_{\text {stw }}[\mathrm{m}]\end{array}$ & 19.74 & 9.76 & $9.98-29.51$ & 49.46 & 2.88 \\
\hline $\begin{array}{l}\text { Ratio of the perimeter of a typical } \\
\text { window } P_{t w} \text { to the area of a typical } \\
\text { window, } A_{t w} P_{t w} / A_{t w}\left[\mathrm{~m}^{-1}\right]\end{array}$ & 2.06 & 0.40 & $1.67-2.46$ & 19.18 & 0.04 \\
\hline $\begin{array}{l}\text { Ratio of the perimeter of a opening } \\
\text { sashes of a typical window to the area } \\
\text { of a typical window, } P_{s t w} / A_{t w}\left[\mathrm{~m}^{-1}\right]\end{array}$ & 4.56 & 0.72 & $3.84-5.28$ & 15.80 & -0.32 \\
\hline
\end{tabular}


The $A_{w} / A_{u}$ indicator $=0.20$ is exceeded by $0.01-0.11$ in 20 out of 50 of the analysed buildings. In the available publications in which the results of the research conducted in Belgium and Scotland were presented, in office buildings (not deviating from the currently applicable heat and energy standards) and in school buildings in Brazil the values of $A_{w} / A_{u}$ were found to amount to $16-32 \%$ [60], 10-27\%, 12-29\% [61] and in USA to $10-25 \%$ [62].

In the case of the analysed education buildings, the average value of the said indicator was $20.1 \%$. It complies with the recommendations in this respect, concerning rooms intended for work and education, according to which the $A_{w} / A_{u}$ indicator should fall between 0.20 and 0.30 (the required minimum value for rooms intended for long-term occupancy by people should be at least 0.125 ).

The ratio of the windows area to usable area $A_{w} / A_{u}$ in education buildings is presented in Figure 1.

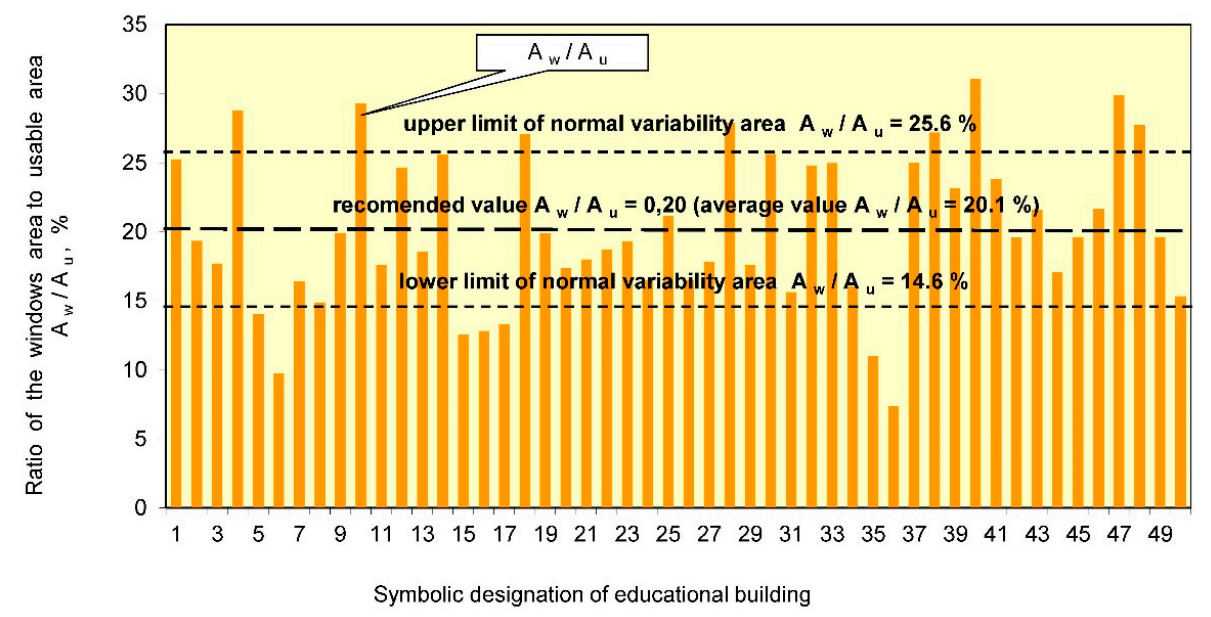

Figure 1. Values of the $A_{w} / A_{u}$ indicator in education buildings.

An indicator of another type, frequently used in analyses of the building glazing area, is the ratio of window area $A_{w}$ to the façade area $A_{f}$ (Figure 2). The average value of the indicator $\left(A_{w} / A_{f}\right)_{a v}=0.244$, with the values in the range $0.1469-0.3616$. It has been found that in only $30 \%$ of schools did the $A_{w} / A_{f}$ indicator fall below 0.2 , which may be assumed to be the optimum value for objects of this type, taking into consideration the reduction of heat loss while ensuring, at the same time, appropriate daylight illumination conditions. In simulation analyses of education buildings in Ireland the average value of $A_{w} / A_{f}$ was $34 \%$ [63].

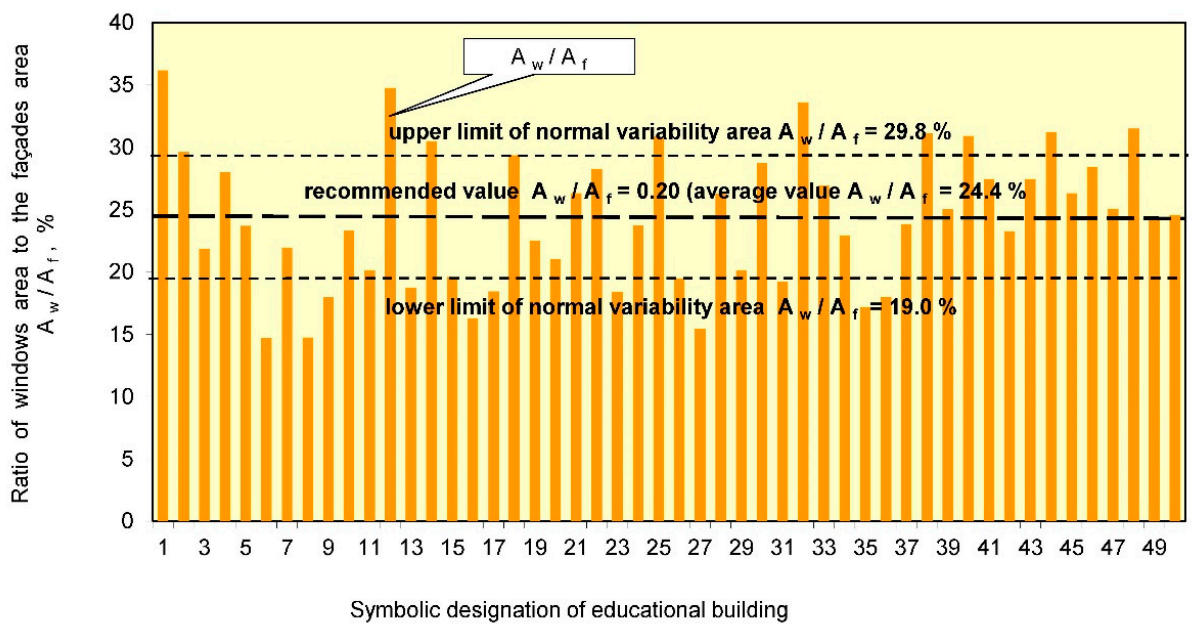

Figure 2. Values of the $A_{w} / A_{f}$ indicator (ratio of windows area to the façades area) in education buildings. 
In the conclusions from the analysis of school buildings in Great Britain conducted in the 1980s, it was suggested that the $A_{w} / A_{f}$ indicator should be $20 \%$. This solution was adopted in the model school and the research conducted proved this choice to be absolutely right. The average value of this indicator for the buildings discussed in this paper and amounting to $A_{w} / A_{f}=24.4 \%$ seems not to differ substantially from the value mentioned above.

Taking into consideration the local meteorological conditions, the surfaces of educational building windows installed on the western and southern façades also seem to be important. These façades are particularly exposed to wind during the heating season. For this reason the values of the glazing indicator for the façades facing the south $S A_{w}$ and all the way to the west $W A_{w}$ are presented in Figure 3.

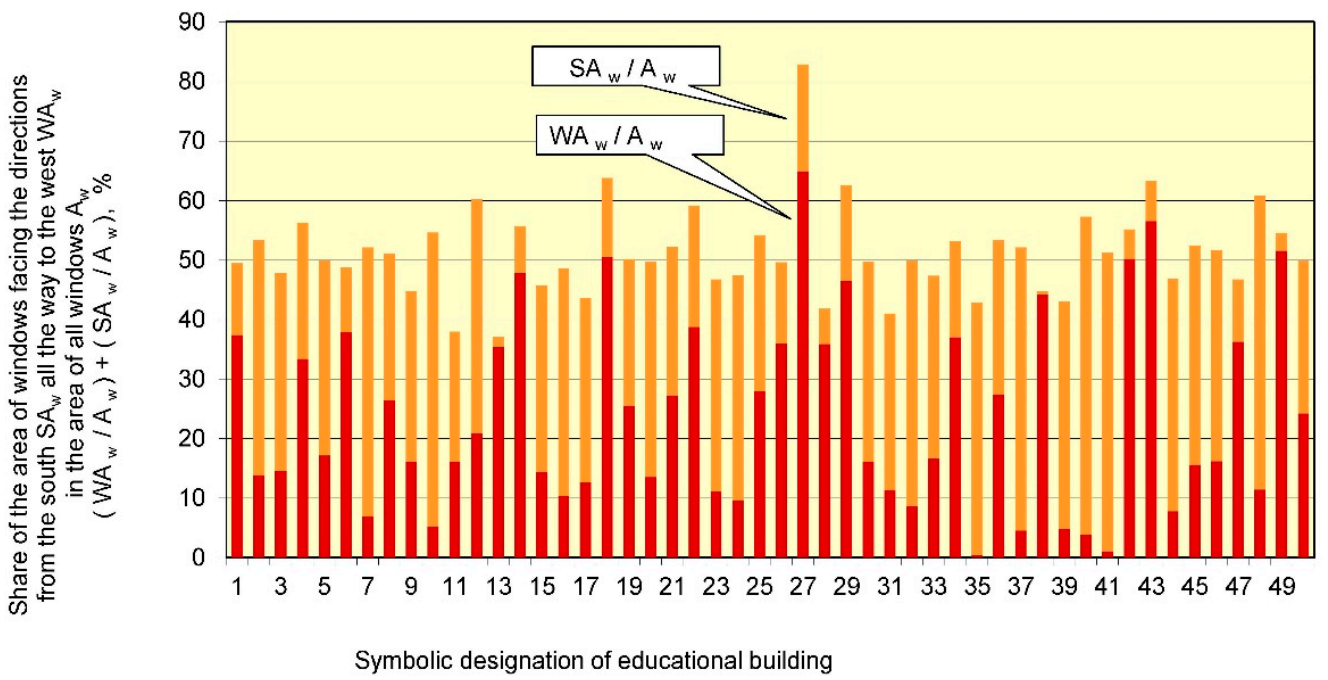

Figure 3. Share of the area of windows facing the directions from the south $S A_{w}$ all the way to the west $W A_{w}$ in the area of all windows $A_{w}$ in education buildings.

The analysis also revealed that the eastern and western façades have the largest glazing area $E A_{w} / A_{f}=0.2471, W A_{w} / A_{f}=0.2401$, respectively. None of the publications available to the author includes research concerning glazing of individual façades in comparison with the directions of local winds.

The analysed classroom windows are typical windows. The size of a typical window $A_{t w}$ ranges from $1.80 \mathrm{~m}^{2}$ (usually in the buildings erected before 1959) (always below $4.00 \mathrm{~m}^{2}$ ), up to $19.40 \mathrm{~m}^{2}$ in the schools erected after 1959 (in majority of cases it is $5.00 \mathrm{~m}^{2}$ ). The larger the area of windows, the longer their perimeter (Figure 4) and the more notable the increase of the number and perimeter of opening sashes of such a window (Figure 5), and thus, the total of these two perimeters. Furthermore, when the perimeter of a typical window $P_{t w}$ increases by $260 \%$ at the maximum, the perimeter of opening sashes $P_{s t w}$ increases by $680 \%$ (Figure 6). It has also been noted that the $P_{t w} / A_{t w}$ indicator increases as the window area $A_{t w}$ decreases (Figure 7), and the large perimeter of windows is the cause of more significant leaks in the woodwork.

The point of view from which this problem is analysed in this paper is hardly present in the literature. There is, however, quite a large number of publications which associate window air permeability with the functioning of the gravity ventilation e.g., in [64-67]. 


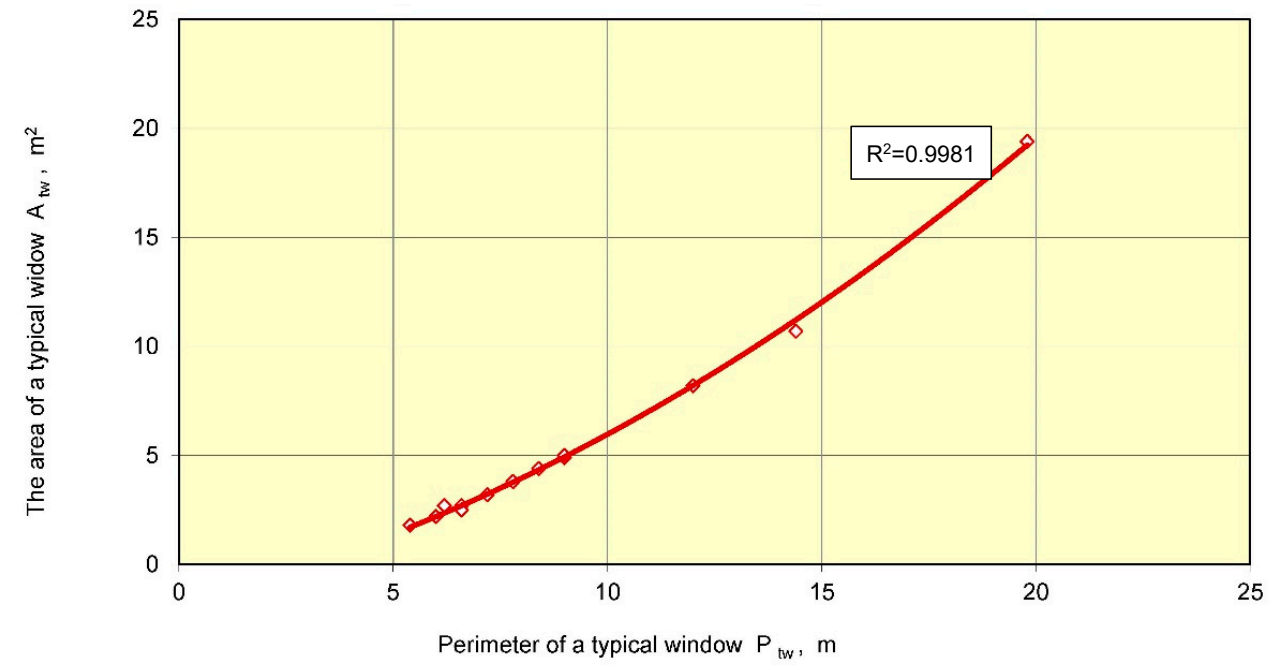

Figure 4. Relations between the area of a typical window $A_{t w}$ and perimeter of a typical window $P_{t w}$ in education buildings.

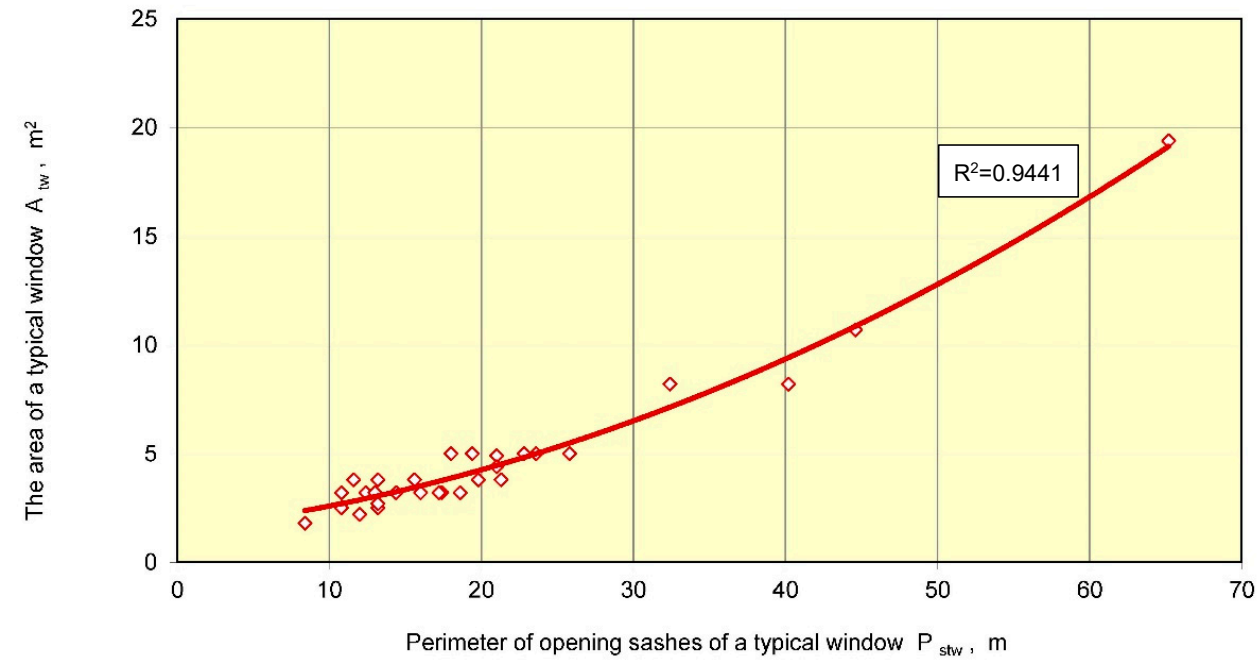

Figure 5. Relations between the area of a typical window $A_{t w}$ and perimeter of opening sashes of a typical window $P_{s t w}$ in education buildings.

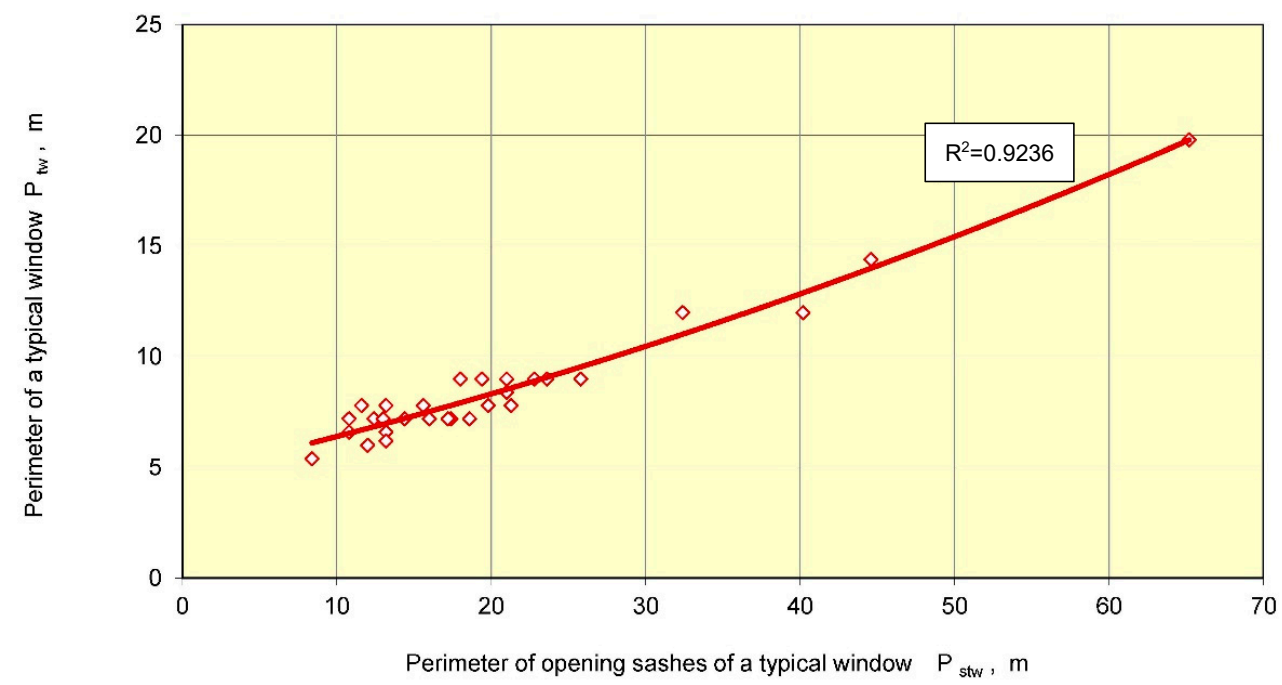

Figure 6. Relations between the perimeter of a typical window $P_{t w}$ and perimeter of opening sashes of a typical window $P_{s t w}$ in education buildings. 


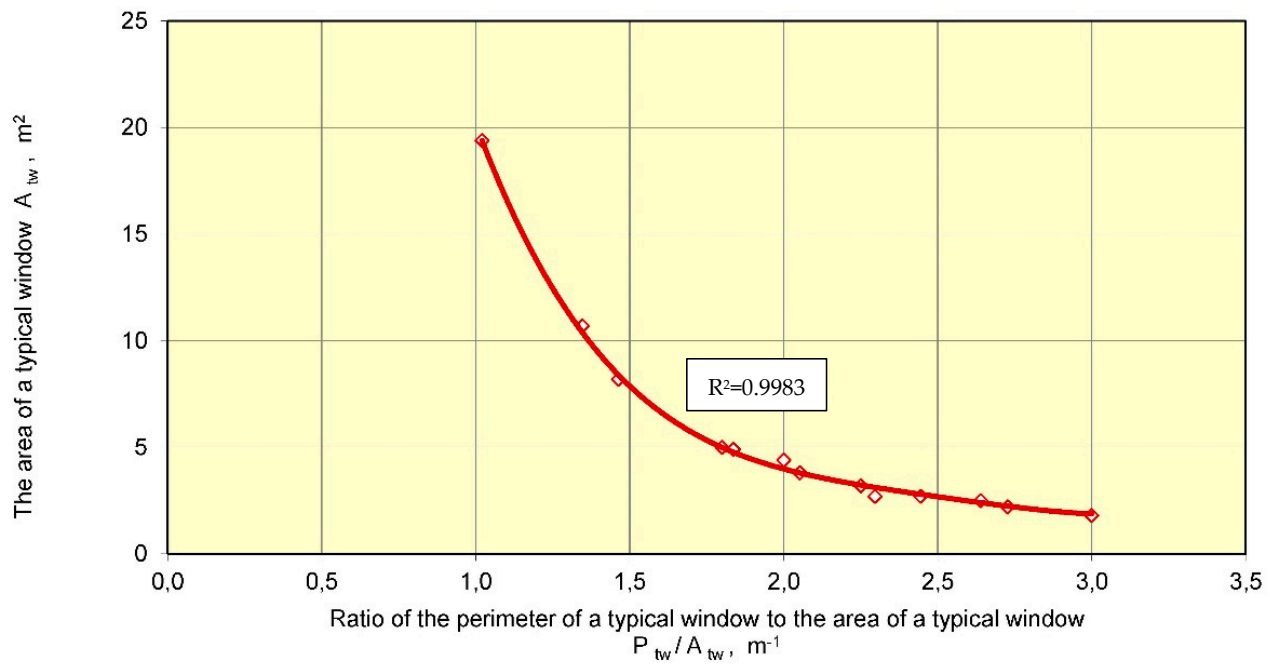

Figure 7. Relations between the area of a typical window $A_{t w}$ and the ratio of the perimeter of a typical window $P_{t w}$ to the area of a typical window $A_{t w}$ in education buildings.

In analysing the technical condition of education buildings, particular attention was paid to the windows and to the issue of their division into opening and fixed sashes. In this case the form often prevails over functional aspects of the window. Large areas of opening sashes are often damaged in the course of their use which makes it impossible to close them properly. This results in excessive air permeability and high air infiltration. The defects which occur most often are those causing excessive air permeability of windows (this applies to, on average, approximately $91 \%$ of the usable area of education buildings). Technical conditions of windows was assessed as bad in 49 out of 50 analysed buildings.

\subsection{The Fresh Air Requirements}

For the examined education buildings it was necessary to determine the fresh air rate requirements for a classroom. The outdoor air rate requirements for natural ventilation due to the cubature of a classroom (air change rate) was calculated from the equation:

$$
Q_{s c}=n V_{c},
$$

where:

$Q_{s c}$ outdoor air rate requirements for natural ventilation due to the cubature of a classroom $\left[\mathrm{m}^{3} / \mathrm{h}\right]$;

$n \quad$ air changes per hour in the classroom [ac/h]; (people outdoor air rate $n=1.5 \mathrm{ac} / \mathrm{h}$ taking into account the Polish requirements);

$V_{c} \quad$ volume of the classroom $\left[\mathrm{m}^{3}\right]$.

Whereas the outdoor air rate requirements due to the number of persons in a classroom was calculated from the equation:

$$
Q_{S N}=q_{p} N_{S C}
$$

where:

$Q_{S N}$ outdoor air rate requirements due to the number of persons in a classroom $\left[\mathrm{m}^{3} / \mathrm{h}\right]$;

$q_{p} \quad$ people outdoor air rate per 1 student in the classroom $\left[\mathrm{m}^{3} /(\right.$ students.h)]; (adopted for the calculation $q_{p}=20 \mathrm{~m}^{3} /$ (students.h)-this corresponds to $q_{p}=5.55 \mathrm{~L} /$ (students.h). This is the minimum outdoor air rate that is required in Poland);

$N_{s c}$ number of students in the classroom [students/classroom].

Other standards for this issue are primarily ASHRAE Standard 62.1-2019 ( $q_{p}=5.00 \mathrm{~L} /$ (students h)) and EN 16798-1:2019 ( $q_{p}=5.00 \mathrm{~L} /($ students h)) $[58,68,69]$. 


\subsection{Quantity of Fresh Air That Could Flow into the Classrooms}

The essential value for the present analysis in order to determine the amount of air which may leak into the windows in the examined rooms. European Standard EN 14351-1:2006+A2:2016 indicates the standard EN 12207:2016 as appropriate for the determination of air permeability of windows [1,2]. At the same time, the standard EN 14351-1:2006+A2:2016 allows restriction of windows or determining these parameters by the each country, for the proper implementation of economic and building requirements posed in these countries. These European standards define four windows classes in terms of air permeability, inter alia, using rate of the air permeability $q_{100 K L}$ through $1 \mathrm{~m}$ window leak, expressed in $\mathrm{m}^{3} /(\mathrm{h} \mathrm{m})$. The terms of appointment of this size in laboratory conditions is specified in EN 1026:2016 [70].

In Poland, the traditional parameter of air infiltration through windows and doors, reported in the Technical Approvals was an air leakage coefficient $a$ which is defined as the amount of air that penetrates within $1 \mathrm{~h}$ through a window leak length of $1 \mathrm{~m}$ at a pressure difference $1 \mathrm{daPa}$, expressed in $\mathrm{m}^{3} /\left(\mathrm{h} \cdot \mathrm{m} \cdot \mathrm{daPa}^{2 / 3}\right)$ and determined from the equation [62]:

$$
a=\frac{Q}{\sum l(\Delta p)^{\frac{2}{3}}},
$$

where:

a calculated air leakage coefficient $\left[\mathrm{m}^{3} /\left(\mathrm{h} \cdot \mathrm{m} \cdot \mathrm{daPa}^{2 / 3}\right)\right]$;

$Q \quad$ quantity of infiltrating air through leaks in windows $\left[\mathrm{m}^{3} / \mathrm{h}\right]$;

$\Sigma l$ total length of all edges of opening sashes or door sashes of the window or door frame opening, together with the frame perimeter [m];

$\Delta p_{a}$ vdifference of the pressure on both sides of the analysed barrier caused by the wind blowing with certain speed $[\mathrm{Pa}]$.

If the pressure difference is expressed in $\mathrm{Pa}$, the Equation (3) has the form:

$$
a=\frac{Q}{\sum l\left(\frac{\Delta p}{10}\right)^{\frac{2}{3}}},
$$

From Equation (4), er can calculate the quantity of infiltrating air $Q$ through leaks in windows:

$$
Q=a \sum l\left(\frac{\Delta p}{10}\right)^{\frac{2}{3}},
$$

However, in terms of European regulations, European standard EN 12,207 defines a parameter called "permeability of reference" [2]. This is the air permeability relative to the total widow area and / or the length of the contact hole-total length of all edges of opening sashes of the window frame opening, together with the frame perimeter, defined at a pressure of $100 \mathrm{~Pa}$. For each class of EN sets as the limit, the value of air permeability calculated from measurements obtained at different test pressures on the quantity of air which corresponds to $100 \mathrm{~Pa}$ test pressure:

$$
q_{100 K L}=Q \sum l\left(\frac{\Delta p}{100}\right)^{\frac{2}{3}},
$$

From Equation (6) we can also calculate the quantity of infiltrating air $Q$ through leaks in windows:

$$
Q=q_{100 K L} \sum l\left(\frac{\Delta p}{100}\right)^{\frac{2}{3}}
$$


Comparing Equations (5) and (7) we prepared the following:

$$
q_{100 K L} \sum l\left(\frac{\Delta p}{100}\right)^{\frac{2}{3}}=a \sum l\left(\frac{\Delta p}{10}\right)^{\frac{2}{3}},
$$

From Equation (8) we calculated $q_{100 K L}$ :

$$
q_{100 K L}=a 10^{\frac{2}{3}}=a 4.6416
$$

The Equation (9) was used to calculate the air permeability rate $q_{100 K L}$ to $1 \mathrm{~m}$ long leak window with the leak based on the known value of air leakage rate $a$. Taking into account the differences between the methodology for determining air leakage coefficient $a$ and air permeability rate $q_{100 K L}$ Equation (9) should be regarded as approximate. For the issues analysed here, an approximation seems to be sufficient. The difference between the results of calculations made by Equations (5) and (7) does not exceed $0.5 \%$. Given these European standards and given that the infiltration coefficient $a$ is expressed in $\mathrm{m}^{3} /\left(\mathrm{h} \cdot \mathrm{m} \cdot \mathrm{daPa}^{2 / 3}\right)$ (which was and still is used in Poland) we here present the approximately corresponding values of the air permeability rate $q_{100 K L}$ expressed in $\mathrm{m}^{3} /(\mathrm{h} \cdot \mathrm{m})$.

For the purpose of implementation of the logical design presented in Section 2.1, the following conditions were assumed:

- for the calculations of a standard demand for outdoor air in classrooms with gravity ventilation (Equations (1) and (2), the following was assumed for two analysed requirements: $n=1.5$ air changes per hour $(n=1.5 \mathrm{ac} / \mathrm{h})$ per average volume of the classroom, $20 \mathrm{~m} 3$ of outdoor air per person staying in the analysed room;

- on the basis of our own data (and other sources it was assumed that the average speed of wind in Czestochowa in the heating season is between 3.5-4.0 m/s [56,59]. The wind blowing with such a speed causes differential pressure of 7-10 Pa;

- $\quad$ for the purpose of calculating the air leakage coefficient $a$, for the established results of inspection of the poor technical condition of the majority of windows, we assumed a value of $4.5 \mathrm{~m}^{3} /\left(\mathrm{m} \cdot \mathrm{h} \cdot \mathrm{daPa}^{2 / 3}\right)\left(\sim 20.8872 \mathrm{~m}^{3} /(\mathrm{h} \cdot \mathrm{m})\right.$ ) (which is consistent with the information presented in Table 2);

- $\quad$ quantity of infiltrating air $Q$ through leaks in windows was calculated on the basis of the Equation (5). One can also use Equation (7).

Approximate data regarding the air leakage coefficient for windows in existing buildings are presented in Table 4.

\begin{tabular}{|c|c|c|c|}
\hline Construction Element & $\begin{array}{l}\text { Type of Sealing, } \\
\text { Level of Wear }\end{array}$ & $\begin{array}{c}\text { Leakage Rate } \\
a\left[\mathrm{~m}^{3} /\left(\mathrm{m} \cdot \mathrm{h} \cdot \mathrm{daPa}^{2 / 3}\right)\right]\end{array}$ & $\begin{array}{c}\text { Air Permeability Rate } \\
q_{100 K L}\left[\mathrm{~m}^{3} /(\mathrm{m} \cdot \mathrm{h})\right]\end{array}$ \\
\hline \multirow{3}{*}{$\begin{array}{l}\text { Windows, glazed balcony } \\
\text { door or entrance door }\end{array}$} & Slide, sealed & $0.2-0.3$ & $0.9283-1.3925$ \\
\hline & Frequently opened, sealed & $0.3-0.6$ & $1.3925-2.7848$ \\
\hline & $\begin{array}{l}\text { With minimum sealing, } \\
\text { damaged, no sealing }\end{array}$ & $\begin{array}{l}\text { above } \\
1.1-3.5\end{array}$ & $\begin{array}{c}\text { above } \\
5.1058-16.2456\end{array}$ \\
\hline
\end{tabular}

Table 4. Approximate values of the rate of outdoor air leakage through leaks [59].

The values of the air leakage coefficient for new openable windows and balcony doors should be:

- $\quad a \leq 0.3 \mathrm{~m}^{3} /\left(\mathrm{h} \cdot \mathrm{m} \cdot \mathrm{daPa}^{2 / 3}\right)\left(q_{100 K L} \leq 1.3925 \mathrm{~m}^{3} /(\mathrm{h} \cdot \mathrm{m})\right)$, if the fresh air gets inside through air inlet vents;

- $\quad 0.5<a \leq 1.0 \mathrm{~m}^{3} /\left(\mathrm{h} \cdot \mathrm{m} \cdot \mathrm{daPa}^{2 / 3}\right)\left(2.3208<q_{100 K L} \leq 4.6416 \mathrm{~m}^{3} /(\mathrm{h} \cdot \mathrm{m})\right)$, in other instances.

The answer to the question of whether these values are sufficient for correct functioning of natural (gravity) ventilation will be presented later. 


\section{Main Research Results and Discussion}

\subsection{Standardized Quantity of Fresh Air for Proper Ventilation in the Classroom}

Results of the calculations of the necessary quantity of the air delivered through the ventilation system into a standard classroom, which results from applicable norm requirements in this respect and may depend on the cubature of the room (air change rate) or on the number of people staying in the room (volume of air per person), are presented in Figure 8 . The values resulting from the demand for fresh air in a group of people occupying classrooms are approximately $50 \%$ higher than those resulting from room cubature and assumed numbers of air changes per hour. Such a situation could have been expected since it is typical for the majority of public buildings which may be temporarily occupied by large numbers of users of such facilities.

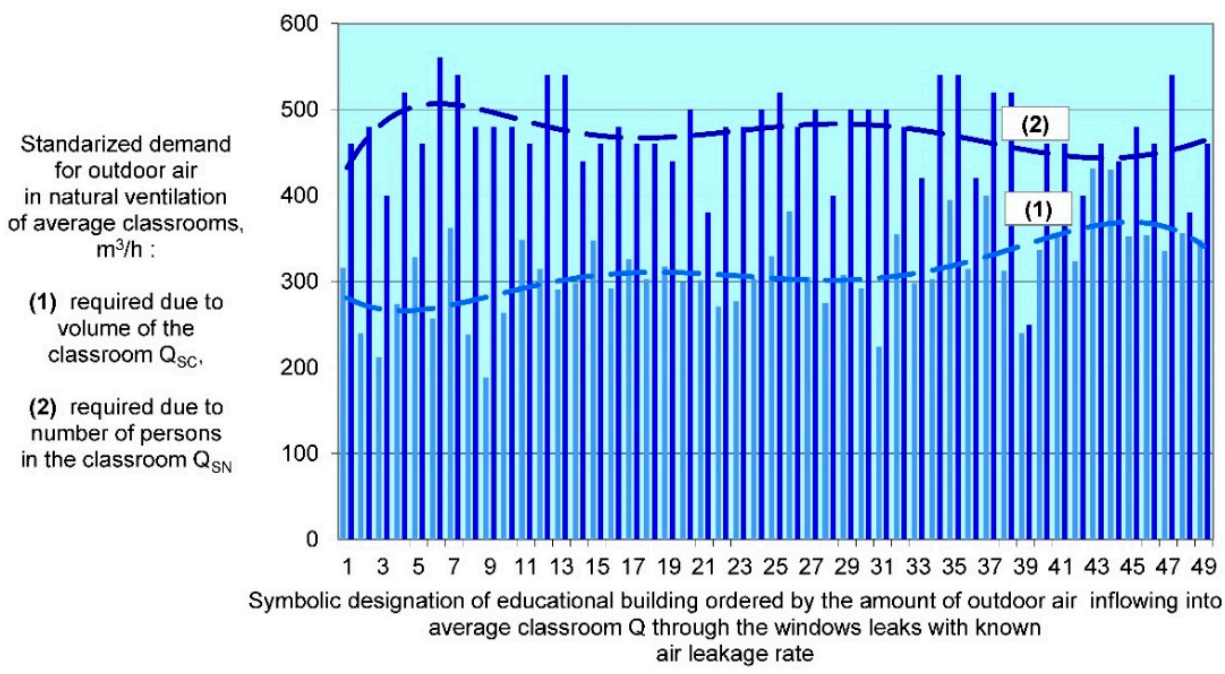

Figure 8. Standardized demand for outdoor air in natural ventilation of average classrooms in the analysed education buildings.

\subsection{Quantity of Fresh Air Flowing into the Classroom}

The windows in the investigated education buildings are draughty windows in bad and very bad technical conditions. After their replacement with new windows, they will meet the requirements for the air leakage coefficient for new openable windows and balcony doors. Taking into account the cases mentioned and to complement the main material of the analysis, we have separated and presented additional charts in Figures 9-12. They were made for a pressure difference of $10 \mathrm{~Pa}$, which corresponds to a wind speed of $4 \mathrm{~m} / \mathrm{s}$, for:

- draughty windows in a bad $\left(a=4.5 \mathrm{~m}^{3} /\left(\mathrm{m} \mathrm{h} \mathrm{daPa}^{2 / 3}\right)\right.$, corresponding to $q_{100 K L}=$ $20.8872 \mathrm{~m}^{3} /(\mathrm{h} \cdot \mathrm{m})$ (Figure 9$)$ ) or very bad $\left(a=7.0 \mathrm{~m}^{3} /\left(\mathrm{m} \mathrm{h} \mathrm{daPa}^{2 / 3}\right)\right.$, corresponding to $q_{100 K L}=32.4912 \mathrm{~m}^{3} /(\mathrm{h} \cdot \mathrm{m})$ (Figure 10)) technical condition;

- $\quad$ good quality windows within the limits of the requirements for new windows (in the presented cases: $a=0.6 \mathrm{~m}^{3} /\left(\mathrm{m} \mathrm{h} \mathrm{Pa}^{2 / 3}\right)$, corresponding to $q_{100 K L}=1.13925 \mathrm{~m}^{3} /(\mathrm{h} \cdot \mathrm{m})$ (Figure 11); $a=0.6 \mathrm{~m}^{3} /\left(\mathrm{m} \mathrm{h} \mathrm{daPa}{ }^{2 / 3}\right)$, corresponding to $q_{100 K L}=2.7848 \mathrm{~m}^{3} /(\mathrm{h} \cdot \mathrm{m})$ (Figure 12).

They depict three columns in different shades of blue drawn up for individual buildings. The height of the columns presented on Figures 9-12 depends on: the regulatory quantity of the amount of air delivered to classrooms depending on the number of people staying in the classroom, the regulatory quantity of air depending on the cubature of classrooms and air change rate per hour and the estimated theoretical quantity of the air infiltrating into the analysed rooms through window leaks at a certain wind force and direction. 


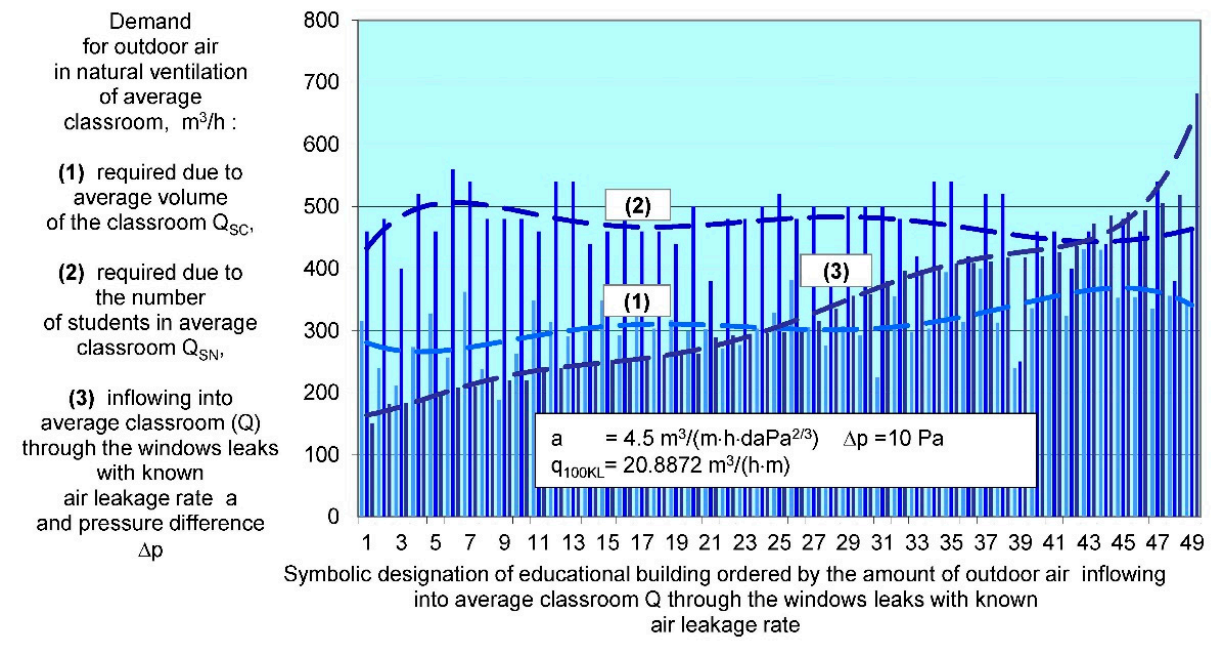

Figure 9. The quantity of air flowing into the classroom from the outside through draughty windows in bad technical condition $a=4.5 \mathrm{~m}^{3} /\left(\mathrm{m} \mathrm{h} \mathrm{daPa}^{2 / 3}\right)$, corresponding to $q_{100 K L}=20.8872 \mathrm{~m}^{3} /(\mathrm{h} \cdot \mathrm{m})$.

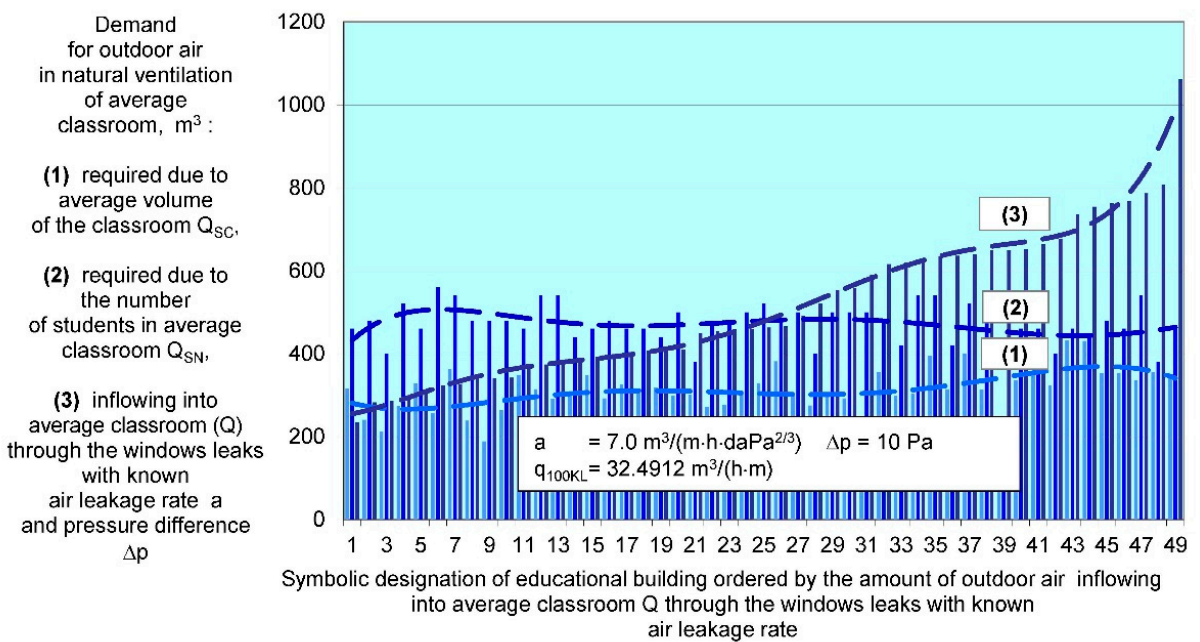

Figure 10. The quantity of air flowing into the classroom from the outside through draughty windows in very bad technical condition $a=7.0 \mathrm{~m}^{3} /\left(\mathrm{m} \mathrm{h} \mathrm{daPa}^{2 / 3}\right)$, corresponding to $q_{100 K L}=32.4912 \mathrm{~m}^{3} /(\mathrm{h} \cdot \mathrm{m})$.

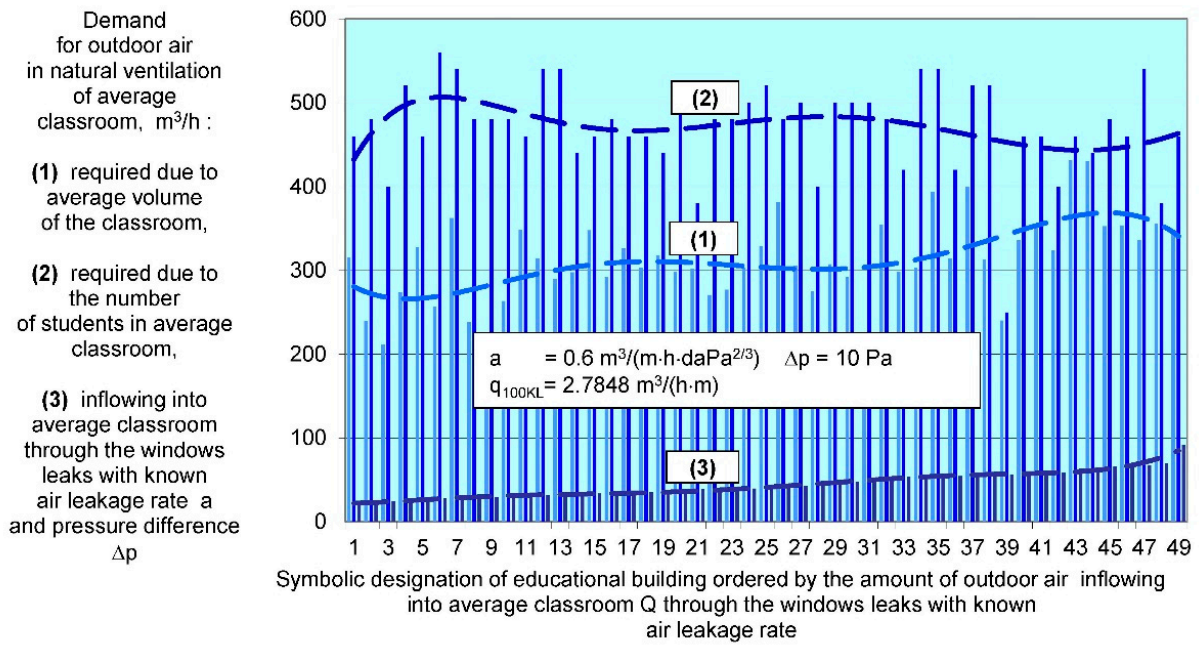

Figure 11. The quantity of air flowing into the classroom from the outside through new windows that meet the technical requirements- $a=0.6 \mathrm{~m}^{3} /\left(\mathrm{m} \mathrm{h} \mathrm{daPa}^{2 / 3}\right)$, corresponding to $q_{100 K L}=2.7848 \mathrm{~m}^{3} /(\mathrm{h} \cdot \mathrm{m})$. 


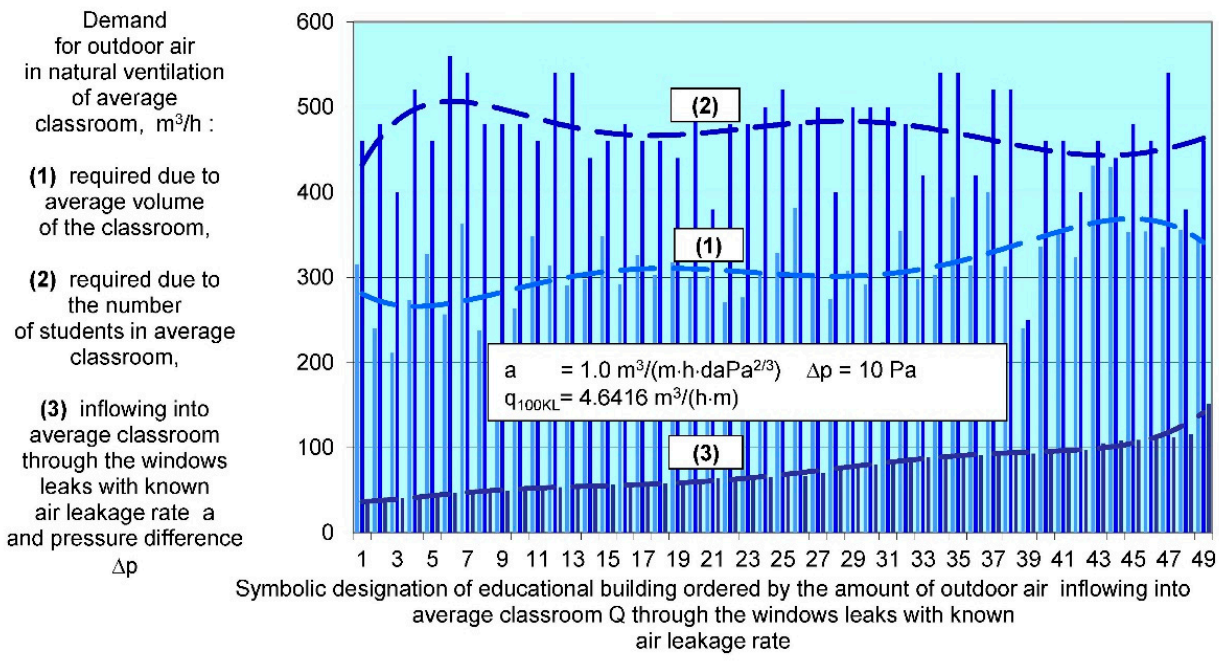

Figure 12. The quantity of air flowing into the classroom from the outside through new windows that meet the technical requirements- $a=1.0 \mathrm{~m}^{3} /\left(\mathrm{m} \mathrm{h} \mathrm{daPa}^{2 / 3}\right)$, corresponding to $q_{100 K L}=4.6416 \mathrm{~m}^{3} /(\mathrm{h} \cdot \mathrm{m})$.

The fundamental graphical analysis using charts covers the cases of windows with different rates of outdoor air leakage $a$. These charts are presented in Figures 13-16. Rates of outdoor air leakage $a$ ranging from 3.5 to $7.0 \mathrm{~m}^{3} /\left(\mathrm{m} \mathrm{h} \mathrm{daPa}^{2 / 3}\right)\left(q_{100 K L}\right.$ from 16.2456 to $32.4912 \mathrm{~m}^{3} /(\mathrm{h} \cdot \mathrm{m})$ ) apply to the windows in a bad or very bad technical condition. In particular, the analysis takes into account the dimensions and lengths of leaks through which the air infiltrates into classrooms. As for rates of outdoor air leakage, on the other hand, $a=0.3 \mathrm{~m}^{3} /\left(\mathrm{m} \mathrm{h} \mathrm{Pa}^{2 / 3}\right)$ and $a=1.0 \mathrm{~m}^{3} /\left(\mathrm{m} \mathrm{h} \mathrm{Pa}^{2 / 3}\right)\left(q_{100 K L}=1.13925 \mathrm{~m}^{3} /(\mathrm{h} \cdot \mathrm{m})\right.$ and $\left.q_{100 K L}=4.6416 \mathrm{~m}^{3} /(\mathrm{h} \mathrm{m})\right)$ refer to new windows (e.g., replaced windows), the air permeability of which, according to the requirements applicable in Poland, should fall within the range from $a=0.3 \mathrm{~m}^{3} /\left(\mathrm{m} \mathrm{h} \mathrm{Pa}^{2 / 3}\right)\left(q_{100 K L}=1.13925 \mathrm{~m}^{3} /(\mathrm{h} \cdot \mathrm{m})\right)$ to $a=1.0 \mathrm{~m}^{3} /\left(\mathrm{m} \mathrm{h} \mathrm{Pa}^{2 / 3}\right)$ $\left(q_{100 K L}=4.6416 \mathrm{~m}^{3} /(\mathrm{h} \cdot \mathrm{m})\right)$.

The average technical conditions of windows in the analysed education buildings were bad. This is the reason why the inflow of outdoor air into classrooms can be considered as a result of the functioning of the natural ventilation of the classrooms. However, only in the case of a significant technical deterioration of windows resulting in a high rate of outdoor air leakage did $a=7.0 \mathrm{~m}^{3} /\left(\mathrm{m} \cdot \mathrm{h} \cdot \mathrm{daPa}^{2 / 3}\right)\left(q_{100 K L}=32.4912 \mathrm{~m}^{3} /(\mathrm{h} \cdot \mathrm{m})\right.$ (Figure 10), that is when the technical conditions of the windows are worse than the average in the analysed objects; the quantity of air coming through the leaks during favourable weather conditions is similar or meets the ventilation requirements in this respect (Figures 10 and 13-16).

It should be remembered here that the rate of outdoor air leakage, as estimated for the classrooms covered by the analysis, amounted to approximately $4.5 \mathrm{~m}^{3} /\left(\mathrm{m} \cdot \mathrm{h} \cdot \mathrm{daPa}^{2 / 3}\right)$ (the rate of outdoor air permeability $\left(q_{100 K L}\right) 20.8872 \mathrm{~m}^{3} /(\mathrm{h} \cdot \mathrm{m})$ (Figures 9 and 13-16).

In the case of wind blowing from a direction adequate for the layout of windows on the building façade, at the speed of $4.0 \mathrm{~m} / \mathrm{s}$ (which is the most frequent, though not the only type of wind blowing in the discussed location) the said rate of outdoor air leakage gives only a possibility for the inflow of air in the quantity required by the criterion defined as the required amount of air change per hour (Figure 9). This quantity of fresh air is much less than that resulting from the average number of persons staying in the classroom. When the number of students staying in the classroom is equal to or higher than the average number of students per classroom, then the quantity of fresh air is insufficient. 


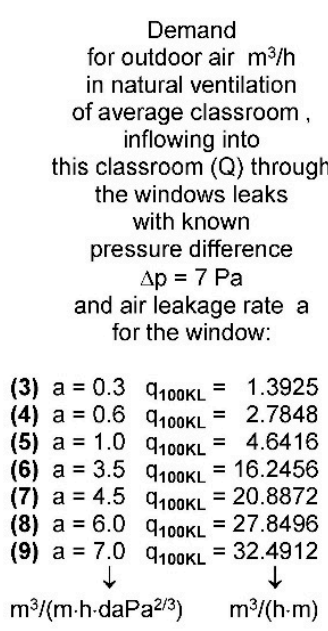

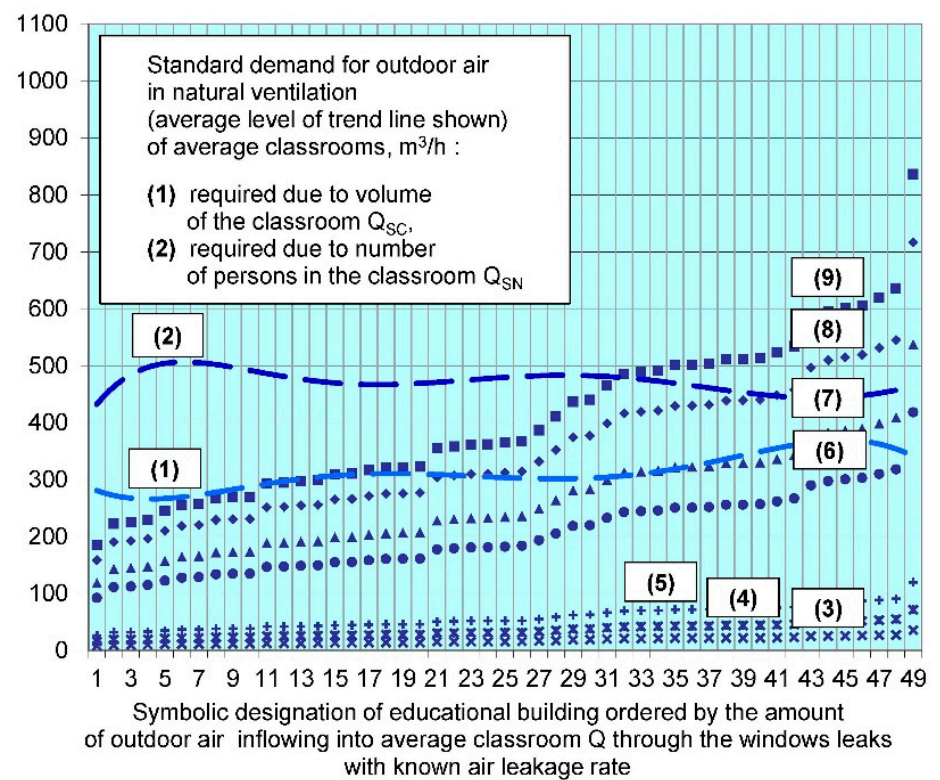

Figure 13. The quantity of air flowing into the classroom from the outside through the windows with different rates of outdoor air leakage $a$, in $\mathrm{m}^{3} /\left(\mathrm{m} \mathrm{h} \mathrm{daPa}^{2 / 3}\right)$ and their corresponding outdoor air permeability $q_{100 K L}$ in $\mathrm{m}^{3} /(\mathrm{h} \cdot \mathrm{m})$ for $\Delta p=7 \mathrm{~Pa}$.


Figure 14. Coverage of the demand for sufficient (with respect to the requirements) quantity of air flowing into the classroom from the outside through the windows with different rates of outdoor air leakage $a$, in $\mathrm{m}^{3} /\left(\mathrm{m} \mathrm{h} \mathrm{daPa}^{2 / 3}\right)$ and their corresponding $q_{100 K L}$ in $\mathrm{m}^{3} /(\mathrm{h} \cdot \mathrm{m})$ for $\Delta p=7 \mathrm{~Pa}$.

This situation may, of course, be changed by opening the windows from time to time, which as it follows from the research, is avoided by the users of education buildings during the heating season. This situation is definitely much more advantageous for natural ventilation than outdoor air inflow through new, air-tight windows (Figures 11 and 12). This is probably the reason why no significant symptoms of insufficient ventilation have been found. This applies to education buildings where the average value of air leakage coefficient $a$ was at the level of $4.5 \mathrm{~m}^{3} /\left(\mathrm{m} \cdot \mathrm{h} \cdot \mathrm{daPa}^{2 / 3}\right)$ and the average value of outdoor air permeability $q_{100 K L}$ was at the level of $20.8872 \mathrm{~m}^{3} /(\mathrm{h} \cdot \mathrm{m})$. 


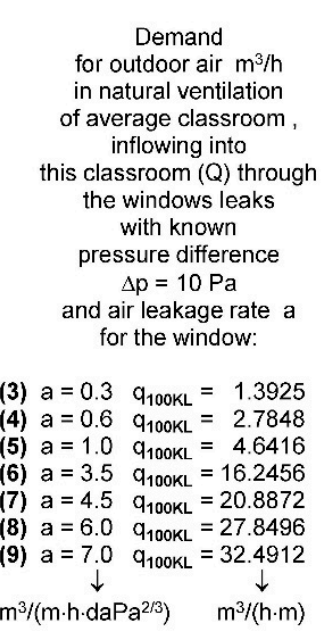

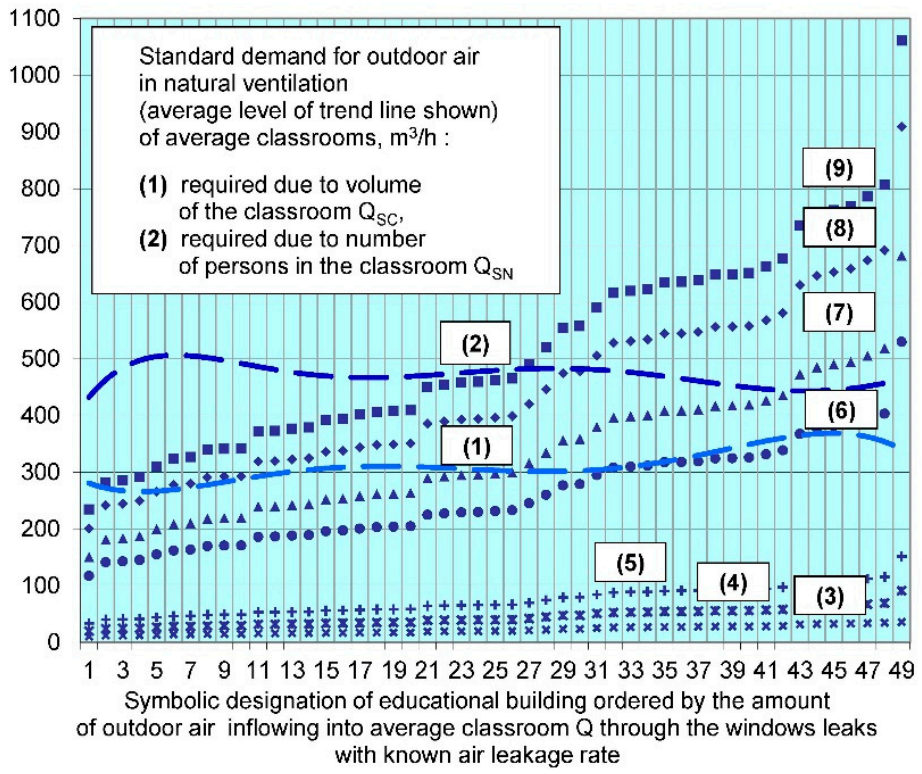

Figure 15. The quantity of air flowing into the classroom from the outside through the windows with different rates of outdoor air leakage $a$, in $\mathrm{m}^{3} /\left(\mathrm{m} \mathrm{h} \mathrm{daPa}^{2 / 3}\right)$ and their corresponding outdoor air permeability $q_{100 K L}$ in $\mathrm{m}^{3} /(\mathrm{h} \cdot \mathrm{m})$ for $\Delta p=10 \mathrm{~Pa}$.

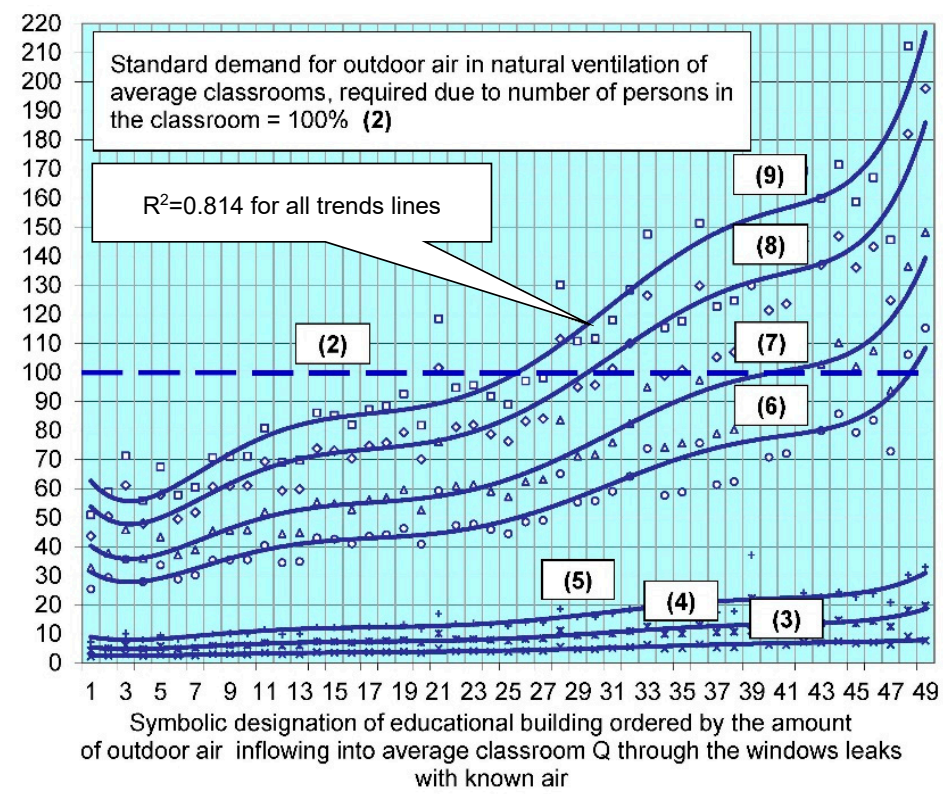

Figure 16. Coverage of the demand for sufficient (with respect to the requirements) quantity of air flowing into the classroom from the outside through the windows with different rates of outdoor air leakage $a$, in $\mathrm{m}^{3} /\left(\mathrm{m} \cdot \mathrm{h} \cdot \mathrm{daPa}^{2 / 3}\right)$ and their corresponding outdoor air permeability $q_{100 K L}$ in $\mathrm{m}^{3} /(\mathrm{h} \cdot \mathrm{m})$ for $\Delta p=10 \mathrm{~Pa}$.

The quantity of air flowing into the classroom from the outside through windows that meet the technical requirements $a=0.6 \mathrm{~m}^{3} /\left(\mathrm{m} \mathrm{h} \mathrm{daPa}^{2 / 3}\right)\left(q_{100 K L}=2.7848 \mathrm{~m}^{3} /(\mathrm{h} \cdot \mathrm{m})\right)$ and $a=1.0 \mathrm{~m}^{3} /\left(\mathrm{m} \mathrm{h} \mathrm{daPa}{ }^{2 / 3}\right)\left(q_{100 K L}=4.6416 \mathrm{~m}^{3} /(\mathrm{h} \cdot \mathrm{m})\right)$ (Figures 11 and 12) covers on average only about $12 \%$ and about $21 \%$ of the ventilation needs resulting from the average number of persons staying in the classroom. In the latter case, on average, about $230 \mathrm{~m}^{3}$ of air is missing to meet the applicable ventilation requirements, depending on the cubature of the room (air change rate) and around $400 \mathrm{~m}^{3}$ of air to meet the applicable ventilation requirements depending on the number of people staying in the classroom (volume of air per person) (Figures 13 and 15). Providing the missing quantity of air for classroom by 
installing window air inlet vents, usually at their maximum capacity of about $30 \mathrm{~m}^{3} / \mathrm{h}$, is practically impossible.

In the case of new windows with the rate of outdoor air leakage $a$ from 0.3 to $1.0 \mathrm{~m}^{3}$ / $\left(\mathrm{m} \cdot \mathrm{h} \cdot \mathrm{daPa}^{2 / 3}\right.$ ) (the rate of outdoor air permeability $q_{100 \mathrm{KL}}$ from 1.3925 to $4.6416 \mathrm{~m}^{3} /(\mathrm{h} \cdot \mathrm{m})$, the infiltration of air is critically reduced. The quantity of air delivered to classrooms in this way is in the range of about 3\% (minimum) to about 36\% (maximum) of the needs resulting from proper ventilation requirements (Figures 14 and 16).

\section{Conclusions}

The conducted research and analyses answer the fundamental questions posed in the introduction to this paper, which can be presented here again.

- Is it theoretically possible to supply enough air to satisfy the ventilation requirements? What is the tightness of the windows required to make this possible?

- What are the consequences of the analysis results for the functioning of the gravity ventilation system?

- What are the consequences of the results of the conducted analysis for the modernization and thermo-modernization of school buildings?

Answers to the above questions were the basis of the analysis referred to later in this paper as the theoretical analysis of functioning of natural (gravity) ventilation in class-rooms. The main conclusions related to this analysis are presented below, taking into account the answers to the above questions.

For the examined education buildings it was necessary to determine the fresh air rate requirements for a classroom. The outdoor air rate requirements for natural ventilation can be due to the cubature of a classroom (air change rate) and due to the number of persons in a classroom. The values resulting from the demand for fresh air in a group of people occupying classrooms are approximately $50 \%$ higher than those resulting from room cubature and assumed numbers of air changes per hour. Such a situation could have been expected since it is typical for the majority of public buildings which may be temporarily occupied by large numbers of users of such facilities

The average technical conditions of windows in the analysed educational buildings were bad. This is the reason why the inflow of outdoor air into classrooms can be considered a result of the functioning of the natural ventilation of the classrooms. However, it is only in the case of a significant technical deterioration of windows resulting in a high rate of outdoor air leakage $a=7.0 \mathrm{~m}^{3} /\left(\mathrm{h} \mathrm{m} \mathrm{daPa}{ }^{2 / 3}\right)\left(q_{100 K L}=32.4912 \mathrm{~m}^{3} /(\mathrm{h} \mathrm{m})\right.$ that the technical conditions of the windows are worse than the average in the analysed objects; the quantity of air coming through the leaks during favourable weather conditions is similar or meets the ventilation requirements in this respect. Bearing in mind the above, it should be mentioned that in the survey conducted by the authors in education buildings, respondents pointed out in the first place their significant permeability and related problems. In the surveys, as well as in $\mathrm{CO} 2$ concentration tests conducted in classrooms for verification purposes, there were no signals indicating a long-term and progressive occurrence in the heating season of symptoms suggesting poor air quality in classrooms. However, there were certain problem in the analysed population of buildings, though they cannot be treated as a norm. Therefore, it may be presumed (to the extent possible in the case of an imperfect system of natural ventilation) that the ventilation works relatively well. The results of the analyses show that windows in a bad or very bad technical condition (so inconvenient to use, favoring uncontrolled infiltration and exfiltration of air) thus ensure a relatively satisfactory functioning of the ventilation of classrooms.

It should be remembered here that the rate of outdoor air leakage, as estimated for the classrooms covered by the analysis, amounted to approximately $4.5 \mathrm{~m}^{3} /\left(\mathrm{m} \cdot \mathrm{h} \cdot \mathrm{daPa}^{2 / 3}\right)$ (the rate of outdoor air permeability $\left(q_{100 K L}\right) 20.8872 \mathrm{~m}^{3} /(\mathrm{h} \cdot \mathrm{m})$. In the case of wind blowing from a direction adequate for the layout of windows on the building façade, at the speed of $4.0 \mathrm{~m} / \mathrm{s}$ (which is the most frequent, though not the only type of wind blowing in the discussed location) the said rate of outdoor air leakage gives only the possibility for inflow 
of air in the quantity required by the criterion, defined as the required amount of air change per hour.

The quantity of air flowing from the outside through modernized windows that meet the technical requirements $\left(a=0.6\right.$ to $1.0 \mathrm{~m}^{3} /\left(\mathrm{m} \mathrm{h} \mathrm{daPa}^{2 / 3}\right)$ ) covers on average only about $12 \%$ and about $21 \%$ of the ventilation needs. The quantity of air flowing into the classroom from the outside through windows that meet the technical requirements covers on average only about $12 \%$ and about $21 \%$ of the ventilation needs resulting from the average number of persons staying in the classroom. In the latter case, on average, about $230 \mathrm{~m}^{3}$ of air is missing to meet the applicable ventilation requirements, depending on the cubature of the room (air change rate) and around $400 \mathrm{~m}^{3}$ of air is missing to meet the applicable ventilation requirements depending on the number of people staying in the classroom (volume of air per person). Without installing additional vents in the rooms, or better yet, installing mechanical ventilation with heat recovery, meeting the ventilation norm requirements will be impossible.

Modernization of buildings, including education buildings, taking place in Poland and other countries that have to reduce the heat loss from the heated rooms typically includes improving the insulation of the building envelope, replacement of draughty windows and modernization of the heating system. Modernization of the ventilation system is often forgotten or ignored for economic reasons. It should be remembered that the ventilation and heat recovery system will play an increasingly important role in improving the energy efficiency of buildings. In the case of natural ventilation, conversion to another more effective mechanical ventilation system with heat recovery, able to properly function after replacing the old windows with new airtight windows, should be considered. Despite the existing legal and technical regulations this kind of practice still exists and affects the deterioration of the occupant's comfort.

Author Contributions: Conceptualization, P.L. and A.L.; methodology, P.L. and A.L.; formal analysis, P.L. and A.L.; investigation, P.L. and A.L.; resources, P.L. and A.L.; data curation, P.L. and A.L.; writing—original draft preparation, P.L. and A.L.; writing—review and editing, A.L.; visualization, P.L.; supervision, P.L. and A.L.; project administration, P.L. and A.L.; funding acquisition, P.L. and A.L. All authors have read and agreed to the published version of the manuscript.

Funding: This research received no external funding. Publication of research results was funded in support of the research activities of the Czestochowa University of Technology.

Informed Consent Statement: Not applicable.

Data Availability Statement: Historical meteorological data for the city of Częstochowa for the Freemeteo website https://freemeteo.pl/pogoda/czestochowa/historia/codzienna-historia/?gid=3100946\& station $=4231 \&$ date $=2014-05-08 \&$ language $=$ polish \& country $=$ Poland, accessed on 8 May 2014.

Conflicts of Interest: The authors declare no conflict of interest.

\section{References}

1. EN 14351-1:2006+A2:2016. Windows and Doors_Product Standard, Performance Characteristics—Part 1: Windows and External Pedestrian Doorsets; European Committee for Standardization: Brussels, Belgium, 2016.

2. EN 12207:2016. Windows and Doors-Air Permeability-Classification; European Committee for Standardization: Brussels, Belgium, 2016.

3. Clements-Croome, D.J.; Awbi, H.B.; Bako-Biro, Z.; Kochhar, N.; Williams, M. Ventilation rates in schools. Build. Environ. 2008, 43, 362-367. [CrossRef]

4. Haverinen-Shaughnessy, U.; Shaughnessy, R.J.; Cole, E.C.; Toyinbo, O.; Moschandreas, D.J. An assessment of indoor environmental quality in schools and its association with health and performance. Build. Environ. 2015, 9, 35-40. [CrossRef]

5. Al Horr, Y.; Arif, M.; Katafygiotou, M.; Mazroei, A.; Kaushik, A.; Elsarrag, E. Impact of indoor environmental quality on occupant well-being and comfort: A review of the literature. Int. J. Sustain. Built. Environ. 2016, 5, 1-11. [CrossRef]

6. Fisk, W.J. The ventilation problem in schools: Literature review. Indoor Air 2017, 27, 1039-1051. [CrossRef]

7. Kapalo, P.; Voznyak, O.; Klymenko, H.; Zhelykh, V.; Adamski, M. Perception of air quality in the selected classroom. BoZPE 2019, 8,77-84. [CrossRef]

8. Sarkhosh, M.; Najafpoor, A.A.; Alidadi, H.; Shamsara, J.; Amiri, H.; Andrea, T.; Kariminejad, F. Indoor Air Quality associations with sick building syndrome: An application of decision tree technology. Build. Environ. 2021, 188, 107446. [CrossRef] 
9. Sundell, J.; Levin, H.; Nazaroff, W.W.; Cain, W.S.; Fisk, W.J.; Grimsrud, D.T.; Gyntelberg, F.; Li, Y.; Persily, A.K.; Pickering, A.C.; et al. Ventilation rates and health: Multidisciplinary review of the scientific literature. Indoor Air 2011, 21, 191-204. [CrossRef]

10. Maddalena, R.; Mendell, M.J.; Eliseeva, K.; Chan, W.R.; Sullivan, D.P.; Russell, M.; Satish, U.; Fisk, W.J. Effects of ventilation rate per person and per floor area on perceived air quality, sick building syndrome symptoms, and decision-making. Indoor Air 2015, 25, 362-370. [CrossRef]

11. Wilson, S. Sick buildings. Archit. J. 1993, 6, 37-40.

12. Jafari, M.J.; Khajevandi, A.A.; Najarkola, S.A.M.; Yekaninejad, M.S.; Pourhoseingholi, M.A.; Omidi, L.; Kalantary, S. Associa-tion of sick building syndrome with indoor air parameters. Tanaffos 2015, 14, 55-62.

13. Boslaugh, S.E. Sick Building Syndrome. Encyclopedia Britannica. Available online: https://www.britannica.com/science/sickbuilding-syndrome (accessed on 12 July 2021).

14. Corgnati, S.P.; Corrado, V.; Filippi, M. A method for heating consumption assessment in existing buildings: A field survey concerning 120 Italian schools. Energy Build. 2008, 40, 801-809. [CrossRef]

15. Persily, A.; de Jonge, L. Carbon dioxide generation rates for building occupants. Indoor Air 2017, 27, 868-879. [CrossRef]

16. Kapalo, P.; Vilčeková, S.; Domnita, F.; Bacotiu, C.; Voznyak, O. Determining the Ventilation Rate inside an Apartment House on the Basis of Measured Carbon Dioxide Concentrations-Case Study. In Environmental Engineering, Proceedings of the 10th International Conference on Environmental Engineering, Vilnius, Lithuania, 27-28 April 2017; VGTU Press: Vilnius, Lithuania, 2017; pp. 28-33. [CrossRef]

17. Jayasooriya, V.M.; Rajapaksha, R.M.D.H.; Ng, A.W.M.; Muthukumaran, S. Associations of Indoor Carbon Dioxide Concentration and Symptoms of Sick Building Syndrome in Air-Conditioned Lecture Halls. Research Square. Available online: https: / / www.researchsquare.com/article/rs-95698/v1 (accessed on 5 July 2021).

18. Mishra, A.K.; Schiavon, S.; Wargocki, P.; Tham, K.W. Carbon dioxide and its effect on occupant cognitive performance: A literature review. In Windsor 2020. Resilien Comfort, Proceedings of the 11th Windsor Conference on Thermal Comfort: Resilien Comfort, Windsor, United Kingdom, Planned for 16-19 April 2020 (Cancelled Due to COVID-19); Roaf, S., Nicol, F., Finlayson, W., Eds.; NCEUB: Windsor, UK, 2020; pp. 440-452.

19. Madureira, J.; Paciência, I.; Pereira, C.; Teixeira, J.P.; Fernandes, E.O. Indoor air quality in Portuguese schools: Levels and sources of pollutants. Indoor Air 2016, 26, 526-537. [CrossRef] [PubMed]

20. Goyal, R.; Khare, M. Indoor-outdoor concentrations of RSPM in classroom of a naturally ventilated school building near an urban traffic roadway. Atmos. Environ. 2009, 43, 6026-6038. [CrossRef]

21. Singh, D.; Kumar, A.; Singh, B.; Mina, U.; Singh, B.B.; Jain, V.K. Statistical modeling of $\mathrm{O}_{3}, \mathrm{NO}_{x}, \mathrm{CO}, \mathrm{PM} 2,5$, VOCs and noise levels in commercial complex and associated health risk assessment in an academic institution. Sci. Total Environ. 2016, 572, 586-594. [CrossRef]

22. Zhang, X.; Wargocki, P.; Lian, Z.; Thyregod, C. Effects of exposure to carbon dioxide and bioeffluents on perceived air quality, self-assessed acute health symptoms and cognitive performance. Indoor Air 2017, 27, 47-64. [CrossRef] [PubMed]

23. Huttunen, K. Indoor Air Pollution. In Clinical Handbook of Air Pollution-Related Diseases, 1st ed.; Capello, F., Gaddi, A., Eds.; Springer: Cham, Switzerland, 2018; pp. 107-114. [CrossRef]

24. Chanjuan, S.; Jialing, Z.; Yuchao, G.; Qingyan, F.; Wei, L.; Jun, P.; Yanmin, H.; Zhijun, Z.; Chena, H. Outdoor air pollution in relation to sick building syndrome (SBS) symptoms among residents. Energy Build. 2018, 174, 68-76. [CrossRef]

25. Järvi, K.; Hyvärinen, A.; Täubel, M.; Karvonen, A.M.; Turunen, M.; Jalkanen, K.; Patovirta, R.; Syrjänen, T.; Pirinen, J.; Salonen, H.; et al. Microbial growth in building material samples and occupants' health in severely moisture-damaged homes. Indoor Air 2018, 28, 287-297. [CrossRef]

26. Mendell, M.J.; Macher, J.M.; Kumagai, K. Measured moisture in buildings and adverse health effects: A review. Indoor Air 2018, 28, 488-499. [CrossRef]

27. Gaihre, S.; Semple, S.; Miller, J.; Fielding, S.; Turner, S. Classroom Carbon Dioxide Concentration, School Attendance, and Educational Attainment. J. Sch. Health 2014, 84, 569-574. [CrossRef]

28. Petersen, S.; Jensen, K.L.; Pedersen, A.L.S.; Rasmussen, H.S. The effect of increased classroom ventilation rate indicated by reduced $\mathrm{CO}_{2}$ concentration on the performance of schoolwork by children. Indoor Air 2016, 26, 366-379. [CrossRef]

29. Wargocki, P. Productivity and Health Effects of High Indoor Air Quality. In Encyclopedia of Environmental Health, 2nd ed.; Nriagu, J.O., Ed.; Elsevier: Amsterdam, The Netherlands, 2019; pp. 382-388. [CrossRef]

30. Bogdanovica, S.; Zemitis, J.; Bogdanovics, R. The Effect of $\mathrm{CO}_{2}$ Concentration on Children's Well-Being during the Process of Learning. Energies 2020, 13, 6099. [CrossRef]

31. Wargocki, P.; Porras, J.A.; Contreras-Espinoza, S.S.; Bahnfleth, W. The relationships between classroom air quality and children's performance in school. Build. Environ. 2020, 173, 106749. [CrossRef]

32. Michalik, M.; Mizera, G.; Podbielska-Kubera, A.; Kowalski, H.; Cenian, A. Problems with microclimate in classrooms-Results of measurements and proposed solution. Eco-Energetics 2021, 4, 11-20. [CrossRef]

33. Smedje, G.; Norback, D. Incidence of asthma diagnosis and self-reported allergy in relation to the school environment-A four-year follow-up study in schoolchildren. Intern. J. Tuberc. Lung Dis. 2001, 5, 1059-1066.

34. Cartieaux, E.; Rzepka, M.A.; Cuny, D. Indoor air quality in schools. Arch. Pediatr. 2011, 18, 789-796. [CrossRef] [PubMed]

35. Egorov, A. (Ed.) School Environment: Policies and Current Status, 1st ed.; WHO Regional Office for Europe: Copenhagen, Denmark, 2015; p. 69. 
36. Schools Indoor Pollution and Health Observatory Network in Europe. Executive Summary of the Final Report, 1st ed.; Publications Office of the European Union: Luxembourg, 2014; p. 22. [CrossRef]

37. Vilčeková, S.; Kapalo, P.; Mečiarová, L'; Krídlová Burdová, E.; Imreczeová, V. Investigation of indoor environment quality in classroom-Case Study. Procedia Eng. 2017, 190, 496-503. [CrossRef]

38. Mumovic, D.; Chatzidiakou, L.; Williams, J.J.; Burman, E. Indoor Air Quality in London's Schools, 1st ed.; University of Cambridge: Cambridge, UK, 2018; p. 59.

39. Tahsildoost, M.; Zomorodian, Z.S. Indoor environment quality assessment in classrooms: An integrated approach. J. Build. Phys. 2018, 42, 336-362. [CrossRef]

40. Langer, S.; Ekberg, L.; Teli, D.; Cabovska, B.; Bekö, G.; Wargocki, P. Study of the measured and perceived indoor air quality in Swedish school classrooms. IOP Conf. Ser. Earth Environ. Sci. 2020, 588, 032070. [CrossRef]

41. Chatzidiakou, L.; Mumovic, D.; Summerfield, A.J. Is $\mathrm{CO}_{2}$ a good proxy for indoor air quality in classrooms? Part 1: The interrelationships between thermal conditions, $\mathrm{CO}_{2}$ levels, ventilation rates and selected indoor pollutants. Build. Serv. Eng. Res. Technol. 2015, 36, 129-161. [CrossRef]

42. Wolski, L.; Kamiński, A. The quality of air in study's accommodation based on criterion $\mathrm{CO}_{2}$. Build. Phys. Theory Pract. 2010, 5, 65-69.

43. Luther, M.; Horan, P.; Atkinson, S.E. Examining $\mathrm{CO}_{2}$ levels in school classrooms. In Indoor Air 2014, Proceedings of the 13th International Conference on Indoor Air Quality and Climate, Hong Kong, China, 7-12 July 2014; Curran Associates: Red Hook, NY, USA, 2014; pp. 704-711.

44. Mainka, A.; Zajusz-Zubek, E. Determination on carbon dioxide levels in school buildings: The effect of thermal efficiency improvement. Eng. Protect. Environ. Gliwice 2018, 21, 155-162. [CrossRef]

45. Sowa, J. Air Quality and Ventilation Rates in Schools in Poland-Requirements, Reality and Possible Improvements. In Indoor Air, Proceedings of 9th International Conference on Indoor Air Quality and Climate, CA, USA, 30 June-5 July 2002; The Printing House: Stoughton, MA, USA, 2002; pp. 68-73.

46. Hani, A.; Koiv, T.-A.; Mikola, A. Carbon Dioxide Levels in Educational Institutions. In EE'11, Proceedings of the 6th IASME/WSEAS International Conference on Energy \& Environment, Cambridge, UK, 23-25 February 2011; Bojkovic, Z., Kacprzyk, J., Mastorakis, N., Mladenov, V., Revetria, R., Eds.; World Scientific and Engineering Academy and Society: Stevens Point, WI, USA, 2011; pp. 378-383.

47. Ventilation for Acceptable Indoor Air Quality Standard 62.1; American Society of Heating, Refrigerating and Air-Conditioning Engineers (ASHRAE): Atlanta, GA, USA, 2007.

48. Coley, D.A.; Beisteiner, A. Carbon Dioxide Levels and Ventilation Rates in Schools. Intern. J. Vent. 2002, 1, 45-52. [CrossRef]

49. Kapalo, P.; Voznyak, O.; Yurkevych, Y.; Myroniuk, K.; Sukholova, I. Ensuring comfort microclimate in the classrooms under condition of the required air exchange. East.-Eur. J. Enterp. Technol. 2018, 5, 6-14. [CrossRef]

50. Simanic, B.; Nordquist, B.; Bagge, H.; Johansson, D. Indoor air temperatures, $\mathrm{CO}_{2}$ concentrations and ventilation rates: Long-term measurements in newly built low-energy schools in Sweden. J. Build. Eng. 2019, 25, 100827. [CrossRef]

51. Zemitis, J.; Bogdanovics, R.; Bogdanovica, S. The study of $\mathrm{CO}_{2}$ concentration in a classroom during the covid-19 safety measures. E3S Web Conf. 2021, 246, 01004. [CrossRef]

52. Ortiz, M.; Itard, L.; Bluyssen, P.M. Indoor environmental quality related risk factors with energy-efficient retrofitting of housing: A literature review. Energy Build. 2020, 221, 110102. [CrossRef]

53. Zuhaib, S.; Manton, R.; Griffin, C.; Hajdukiewicz, M.; Keane, M.M.; Goggins, J. An Indoor Environmental Quality (IEQ) assessment of a partially-retrofitted university building. Build. Environ. 2018, 139, 69-85. [CrossRef]

54. Lis, A. Maintaining thermal comfort and air quality in buildings. ZN PCz. Budown. 2019, 25, 137-144. [CrossRef]

55. Freemeteo. Available online: https://freemeteo.pl/pogoda/czestochowa $/$ historia $/$ codzienna-historia/ ?gid=3100946\&station= 4231\&date=2014-05-08\&language=polish\&country=Poland (accessed on 19 March 2021).

56. Sekret, R.; Wilczynski, J. The effect of variations in ambient air temperature and heating season length on the number of degree-days on the example of the city of Czestochowa. Energy Market. J. 2011, 4, 58-63.

57. Ferdyn-Grygierek, J. Efektywność energetyczna ogrzewania i wentylacji modernizowanych budynków szkół. Dist. Heat. Heat. Vent. 2005, 10, 28-31.

58. EN 16798-1:2019. Energy Performance of Buildings_Ventilation for Buildings_Part 1: Indoor Environmental Input Parameters for Design and Assessment of Energy Performance of Buildings Addressing Indoor Air Quality, Thermal Environment, Lighting and Acoustics-Module M1-6; European Committee for Standardization: Brussels, Belgium, 2019.

59. Laskowski, L. Ochrona Cieplna i Charakterystyka Energetyczna Budynku, 2nd ed.; Publishing House of the Warsaw University of Technology: Warsaw, Poland, 2008; p. 174.

60. Gratia, E.; De Herde, A. Design of low energy office buildings. Energy Build. 2003, 35, 473-491. [CrossRef]

61. Krüger, E.L.; Zannin, P.H.T. Acoustic, thermal and luminous comfort in classrooms. Build. Environ. 2004, 39, 1055-1063. [CrossRef]

62. Perez, Y.V.; Capeluto, I.G. Climatic considerations in school building design in the hot-humid climate for reducing energy consumption. Appl. Energy 2009, 86, 340-348. [CrossRef]

63. Hernandez, P.; Burke, K.; Lewis, J.O. Development of energy performance benchmarks and building energy ratings for nondomestic buildings: An example for Irish primary schools. Energy Build. 2008, 40, 249-254. [CrossRef] 
64. Nantka, M.B. Relacje między szczelnościa okien a realizacją zadań tradycyjnej wentylacji budynków wielorodzinnych. Dist. Heat. Heat. Vent. 2004, 1, 21-24.

65. Hwang, R.-L.; Lin, T.-P.; Chen, C.-P.; Kuo, N.-J. Investigating the adaptive model of thermal comfort for naturally ventilated school buildings in Taiwan. Int. J. Biomet. Taichung Taiwan 2009, 53, 189-200. [CrossRef] [PubMed]

66. Pinto, M.; Viegas, J.; de Freitas, V.P. Air permeability measurements of dwellings and building components in Portugal. Build. Environ. 2011, 46, 2480-2489. [CrossRef]

67. Van Den Bossche, N.; Janssens, A. Airtightness and watertightness of window frames: Comparison of performance and requirements. Build. Environ. 2016, 110, 129-139. [CrossRef]

68. ANSI/ASHRAE Standards 62.1-2019. Ventilation for Acceptable Indoor Air Quality; ASHRAE: Atlanta, GA, USA, 2019.

69. CEN/TR 16798-2:2019. Energy Performance of Buildings-Ventilation for Buildings-Part 2: Interpretation of the Requirements in EN 16798-1-Indoor Environmental Input Parameters for Design and Assessment of Energy Performance of Buildings Addressing Indoor Air Quality, Thermal Environment, Lighting and Acoustics (Module M1-6); European Committee for Standardization: Brussels, Belgium, 2019.

70. EN 1026:2016. Windows and Doors_Air Permeability—Test Method; European Committee for Standardization: Brussels, Belgium, 2016. 